\title{
Seasonality in a boreal forest ecosystem affects the use of soil temperature and moisture as predictors of soil $\mathrm{CO}_{2}$ efflux
}

\author{
S. M. Niinistö ${ }^{1, *}$, S. Kellomäki ${ }^{1}$, and J. Silvola ${ }^{2}$ \\ ${ }^{1}$ School of Forest Sciences, University of Eastern Finland, P.O. Box 111, 80101 Joensuu, Finland \\ ${ }^{2}$ Department of Biology, University of Eastern Finland, P.O. Box 111, 80101 Joensuu, Finland \\ * current address: Finnish Forest Research Institute, Vantaa Unit, P.O. Box 18, 01301 Vantaa, Finland
}

Received: 28 February 2011 - Published in Biogeosciences Discuss.: 16 March 2011

Revised: 23 September 2011 - Accepted: 2 October 2011 - Published: 8 November 2011

\begin{abstract}
Our objectives were to identify factors related to temporal variation of soil $\mathrm{CO}_{2}$ efflux in a boreal pine forest and to evaluate simple predictive models of temporal variation of soil $\mathrm{CO}_{2}$ efflux. Soil $\mathrm{CO}_{2}$ efflux was measured with a portable chamber in a Finnish Scots pine forest for three years, with a fourth year for model evaluation. Plot averages for soil $\mathrm{CO}_{2}$ efflux ranged from 0.04 to $0.90 \mathrm{~g} \mathrm{CO}_{2} \mathrm{~m}^{-2} \mathrm{~h}^{-1}$ during the snow-free period, i.e. May-October, and from 0.04 to $0.13 \mathrm{~g} \mathrm{CO}_{2} \mathrm{~m}^{-2} \mathrm{~h}^{-1}$ in winter. Soil temperature was a good predictor of soil $\mathrm{CO}_{2}$ efflux. A quadratic model of $\ln -$ transformed efflux explained $76-82 \%$ of the variation over the snow-free period.

The results revealed an effect of season: at a given temperature of the organic layer, soil $\mathrm{CO}_{2}$ efflux was higher later in the snow-free period (in August and September) than in spring and early summer (in May and June). Regression coefficients for temperature (approximations of a $Q_{10}$ value) of month-specific models decreased with increasing average soil temperatures. Efflux in July, the month of peak photosynthesis, showed no clear response to temperature or moisture. Inclusion of a seasonality index, degree days, improved the accuracy of temperature response models to predict efflux for the fourth year of measurements, which was not used in building of regression models. During peak efflux from mid-July to late-August, efflux was underestimated with the models that included degree days as well as with the models that did not. The strong influence of the flux of photosynthates belowground and the importance of root respiration could explain the relative temperature insensitivity observed in July and together with seasonality of growth of root and root-associated mycorrhizal fungi could explain partial failure of models to predict magnitude of efflux in the peak season from mid-July to August.
\end{abstract}

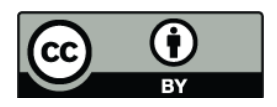

Correspondence to: S. M. Niinistö (sini.niinisto@iki.fi)
The effect of moisture early in the season was confounded by simultaneous advancement of the growing season and increase in temperature. In a dry year, however, the effect of drought was evident as soil $\mathrm{CO}_{2}$ efflux was some $30 \%$ smaller in September than in the previous wet year. Soil temperature was a good overall predictor of soil $\mathrm{CO}_{2}$ efflux, possibly partly because its apparent effect was strengthened by many environmental factors and ecosystem processes that varied in concert with its variation. However, the consistent underestimation by the predictive models for the peak season corroborates recent findings concerning the importance of seasonal changes in carbon inputs to processes producing $\mathrm{CO}_{2}$ in soil.

\section{Introduction}

Soil respiration constitutes most of the total respiration in forest ecosystems (e.g. Janssens et al., 2001). It originates from root and mycorrhizal respiration as well as from respiration by soil microbes and fauna associated with decomposition of organic matter. Soil respiration is often measured as a flux of carbon dioxide from the soil surface i.e. as soil $\mathrm{CO}_{2}$ efflux, which approximately equals soil respiration at annual scale but is influenced by transport conditions over shorter time steps (Raich and Schlesinger, 1992). Soil respiration has been reported to be regulated by two major environmental factors, temperature and moisture, with soil temperature usually having an overriding influence in forest ecosystems (e.g. Witkamp, 1966; Schlesinger, 1977). As soil temperature and moisture often covary in field conditions, it has been difficult to separate their effects (Schlesinger, 1977; Davidson et al., 1998), especially as in many cases the influence of soil moisture in forest ecosystems has been small or indiscernible (e.g. Russell and Voroney, 1998).

Other factors affecting soil respiration and consequently soil $\mathrm{CO}_{2}$ efflux are vegetation and substrate quality,

Published by Copernicus Publications on behalf of the European Geosciences Union. 
ecosystem productivity, relative allocation of primary production above- and belowground, dynamics of the aboveand belowground flora, fauna and microorganisms and landuse and disturbance regimes (Rustad et al., 2000). Substrate availability, in particular, has recently emerged as an important factor behind temporal variation in soil respiration (Högberg et al., 2001; Davidson et al., 2006a). In addition to factors that influence $\mathrm{CO}_{2}$-producing processes i.e. soil respiration, some factors such as snow cover, soil moisture and pressure fluctuations, affect transportation of $\mathrm{CO}_{2}$ from soil to the atmosphere.

The seasonally fluctuating environmental factors and ecosystem processes have been found to result in seasonality of soil $\mathrm{CO}_{2}$ efflux, often studied as a seasonality of the temperature response of the soil $\mathrm{CO}_{2}$ efflux (e.g. Janssens and Pilegaard, 2003; Curiel Yuste et al., 2004). Seasonality affecting soil respiration and soil $\mathrm{CO}_{2}$ efflux can be seen as a combination of the seasonal variation in environmental variables, in substrate availability and quality to different $\mathrm{CO}_{2}$ producing processes, and their interactions.

Boreal forest ecosystems are characterized by distinct seasons: long snow-covered winters and relatively short snowfree seasons comprised of spring, summer and autumn. In a Swedish boreal pine forest, for instance, $95 \%$ of the annual carbon gain can be obtained during the six warmest months (Linder and Lohammer, 1981). Intensity of the growing season can be seen in the rapid increase in photosynthesis early in the season in pines growing in cold climates, compared to a slower change in pines growing in warm climates, which photosynthesize all year (Teskey et al., 1994). Recently, soil $\mathrm{CO}_{2}$ efflux has been observed to be strongly influenced by the flux of recent photosynthates to the roots (Högberg et al., 2001; Keel et al., 2006). Root production of woody plants and grasses as well as mycelial production of ectomycorrhizal fungi have been found to have a seasonal pattern (Wallander et al., 1997, 2001; Steinaker et al., 2010), which most likely influences temporal variation of forest soil $\mathrm{CO}_{2}$ efflux through root respiration and root-associated heterotrophic respiration. Microbial populations and litter inputs also vary seasonally (Lipson et al., 1999). Thus we hypothesize that, in addition to environmental variables such as temperature and moisture, soil $\mathrm{CO}_{2}$ efflux of a boreal forest is affected by other factors that vary according to season, thus resulting in seasonality of soil $\mathrm{CO}_{2}$ efflux.

Here, we investigated temporal variation of soil $\mathrm{CO}_{2}$ efflux and environmental characters that affect this variation in a boreal forest in Finland. Objectives of the study were to assess the level of soil $\mathrm{CO}_{2}$ efflux in this pine ecosystem, to identify factors related to its temporal variation and to evaluate simple predictive models of temporal variation. The 3year measurement campaign enabled us to analyse the effect of season. For model evaluation, a fourth snow-free period of measurements at the same site and on a neighboring site was included.

\section{Materials and methods}

\subsection{Site and weather description}

The study site was located in Huhus $\left(62^{\circ} 52^{\prime} \mathrm{N}, 30^{\circ} 49^{\prime} \mathrm{E}\right)$, some $30 \mathrm{~km}$ from Mekrijärvi Research Station, University of Eastern Finland, Finland. The mean annual temperature at the nearby meteorological station is $2.1^{\circ} \mathrm{C}$, with monthly means of $16.0^{\circ} \mathrm{C}$ for July and $-10.6^{\circ} \mathrm{C}$ for January. Mean annual precipitation is $667 \mathrm{~mm}$, of which an average of $400 \mathrm{~mm}$ falls between May and October (Drebs et al., 2002). Precipitation in May-October during the experiment was 370, 545, and $265 \mathrm{~mm}$ in 1997, 1998, and 1999, respectively. The average air temperature of $13.4{ }^{\circ} \mathrm{C}$ at the site in June-August 1998 was $1.5-2.0^{\circ} \mathrm{C}$ lower than the average for the other study years.

The site was situated in a forested area of managed Scots pine stands (Pinus sylvestris L.). At the beginning of the study, tree height in the area was $10-13 \mathrm{~m}$ for $76 \%$ of the trees. The average leaf-area index was estimated to be $2 \mathrm{~m}^{2} \mathrm{~m}^{-2}$ ground area (Kellomäki and Wang, 1999). The ground was covered with mosses, such as Pleurozium schreberi (Brid.) Mitt., Hylocomnium splendens, Dicranum spp., Polytrichum spp., lichens, such as Cladonia spp. and Cetraria islandica (L.) Ach., and dwarf shrubs, such as bilberry (Vaccinium myrtillus L.) and lingonberry (Vaccinium vitisidaea L.). The pine needle litterfall was $136 \mathrm{~g} \mathrm{~m}^{-2} \mathrm{a}^{-1}$ in average. When soil particles smaller than $20 \mathrm{~mm}$ in diameter were considered, the upper $30 \mathrm{~cm}$ of soil, i.e. the main tree-rooting zone, was classified as podsolized sandy till. Small stones with a diameter of $20-60 \mathrm{~mm}$, however, made up about one sixth of the soil volume. The average depth of the top layer (Oi), which consisted of dead moss and other litter, was $5.7 \mathrm{~cm}$ and that of the underlying organic layer (Oe and $\mathrm{Oa}$ ), i.e. humus, was $2.5 \mathrm{~cm}$.

\subsection{Measurement of soil $\mathrm{CO}_{2}$ efflux and temperature}

Three plots for soil $\mathrm{CO}_{2}$ efflux measurements were established along a transect across a forested area that consisted of pine stands of different age. A weather station (MILOS 500, Vaisala Oy, Helsinki, Finland) was situated along the transect, between Plots 1 and 3: 50m north-northwest from the centre of Plot 1 and $50 \mathrm{~m}$ south-southeast from the centre of Plot 3. Plot 2 was situated $50 \mathrm{~m}$ south-southeast from Plot 1. Plots were placed in two forest stands representing two stages of forest development; Plots 1 and 2 in a stand about 65 years old (thinned about 10 years before, diameter at $1.3 \mathrm{~m} 18.4$ and $21.5 \mathrm{~cm}$ on average in 1998, with 600 and 650 stems ha $^{-1}$, on Plots 1 and 2, respectively) and Plot 3 in a pole-stage forest about 40 years old (with an average diameter of $11.1 \mathrm{~cm}$ and $2000 \mathrm{stems} \mathrm{ha}^{-1}$, not yet thinned). Each plot was $20 \mathrm{~m} \times 20 \mathrm{~m}$ and had 10 randomly chosen permanent measurement points in a $2 \mathrm{~m} \times 2 \mathrm{~m}$ grid. Plot means were used as observations of soil $\mathrm{CO}_{2}$ efflux. 
The additional measurements for model evaluation purposes were made in another Scots pine forest, at some $30 \mathrm{~km}$ distance in Mekrijärvi Research Station in 2000. The measurement plot had the same surface area and an identical layout of 10 randomly chosen, permanent measurement points as the plots in Huhus had. The Mekrijärvi stand was close to the developmental stage of Plot 3 in Huhus, the pole-stage, but pine trees were younger, i.e. 25 years in average. Trees were also smaller, with an average diameter of $5.1 \mathrm{~cm}$. The stand had a clustered structure with 4500 trees $\mathrm{ha}^{-1}$. The Mekrijärvi site on podsolized sandy loam, with thinner litter and organic layers, was somewhat poorer in nutrients compared to Huhus, but similarly a well-drained site. Surface vegetation and soil are described in more detail in Niinistö et al. (2004).

Steel collars with a diameter of $10 \mathrm{~cm}$ and height of $6 \mathrm{~cm}$ were inserted $2-4 \mathrm{~cm}$ into the surface soil so that their tops were level with the tops of the mosses or lichens. A set of five new collar locations were chosen to replace five old locations on plots in 1998 to minimize effects of possible wear on measurement locations. No signs of wear were detected when the new and old locations were compared. $\mathrm{CO}_{2}$ efflux was measured for $120 \mathrm{~s}$ with an infra-red gas analyzer and a portable closed system with an opaque chamber that had a volume of $1.17 \mathrm{dm}^{3}$ (EGM-1 with SRC-1, PP Systems, Hitchin, UK) (Niinistö et al., 2004). The type of measurement chamber can lead to an overestimation of $10-20 \%$ on bare soil (Pumpanen et al., 2004). Values for soil $\mathrm{CO}_{2}$ efflux included dark respiration of mosses and lichens in this study. Measurements were made twice per measuring day, one or two days a week throughout the snow-free period of three years, i.e. from June to October 1997 and from May to October 1998-1999, with a three-week gap in SeptemberOctober 1997 and in August 1998 due to equipment failure. For purposes of model evaluation, measurements of soil $\mathrm{CO}_{2}$ efflux were taken from Plot 1 in Huhus and from a plot with an identical set-up in a young Scots pine stand at nearby Mekrijärvi Research Station in 2000.

Soil was covered with snow from November to late April or early May each year. Winter measurements were made once a month at 4-6 locations in February-April 1999 and March-April 2000. These supplementary measurements were carried out to have annual estimates of soil $\mathrm{CO}_{2}$ efflux but were not used in modelling. Larger chambers with a larger surface i.e. source area and long measurement times were used to capture low winter fluxes for which the smaller surface area of the chamber that was used during the snowfree period could have produced more erratic values. Along a transect on Plots 1 and 3, large closed chambers (volume $54-115 \mathrm{dm}^{3}$, surface area $60 \mathrm{~cm} \times 60 \mathrm{~cm}$ ) were placed on the ground that was cleared of loose snow and they were sealed with snow along the edges. Air in the headspace was sampled every 15 min during each 60 min measurement (Crill, 1991; Larmola et al., 2004). The $\mathrm{CO}_{2}$ concentration of samples was analyzed on the same day with an infrared gas analyzer (Uras
3E, Hartman \& Braun AG, Frankfurt am M., Germany). The flux was calculated based on a linear rise in $\mathrm{CO}_{2}$ concentration in the headspace during the measurement. In connection with chamber measurements, air of undisturbed snow packs was sampled with a syringe and a metal straw that had an opening at the end. The $\mathrm{CO}_{2}$ concentration of air sample was analyzed with an infrared gas analyzer in the laboratory as described above. Snow was sampled and weighed, and its porosity was calculated using the density of pure ice $\left(0.9168 \mathrm{~g} \mathrm{~cm}^{-3}\right)$, which resulted in porosities of $55 \%$ to $79 \%$.

During the snow-free period, soil temperature was measured adjacent to each collar at the time of the $\mathrm{CO}_{2}$ efflux measurement. It was recorded at a depth of about $1-2 \mathrm{~cm}$ in the organic i.e. humus layer, i.e. about $7 \mathrm{~cm}$ below the top of litter layer with a portable temperature probe (STP-1, PP Systems, Hitchin, UK). Temperature of the organic layer was chosen to be monitored because the forest floor i.e. organic layer had previously been identified as the layer in forest soils in which most of $\mathrm{CO}_{2}$ was produced and where a large proportion of respiring root biomass was found (e.g. Bowden et al., 1993). Surface temperature had also been successfully used in modelling of temperature response of soil $\mathrm{CO}_{2}$ efflux in a previous study by our research group (Pajari, 1995 at Mekrijärvi site). Soil temperatures at equivalent depth in the organic layer, measured by a weather station (MILOS 500, Vaisala Oy, Helsinki, Finland) at the centre of the study area, were used in the modelling analyses and to calculate annual estimates of soil $\mathrm{CO}_{2}$ efflux. Temperatures of mineral soil were recorded by the weather station starting in 1998, with the most comprehensive series for temperature at $7 \mathrm{~cm}$ depth in mineral soil, i.e. at $9 \mathrm{~cm}$ from the surface of organic humus layer or at $15 \mathrm{~cm}$ from the top of litter layer. There were some gaps in data in July and September 2000.

Soil temperature measurements made by the weather station situated close to Plot 1 correlated strongly with those made next to soil respiration collars on Plots 1, 2, and 3: On occasions of soil $\mathrm{CO}_{2}$ efflux measurements in the period 1998-1999, Spearman's rho was 0.97 and Pearson correlation $0.97(p<0.001, n=394)$ between plot averages of organic layer temperature and the temperature of the same layer measured by the weather station. Correspondingly, variation in the organic layer temperature measured by the weather station explained $94 \%$ of the temporal variation in plot averages of the organic layer temperature $\left(R^{2}=0.94\right.$ of a linear regression analysis, $p<0.001, n=394$ ).

\subsection{Soil moisture and auxiliary measurements}

Soil moisture was monitored with three different methods: tensiometers, water-content reflectometers and gravimetric sampling (Table 1). Soil water potential was measured with tensiometers starting from the second year (1998) on days for measuring soil $\mathrm{CO}_{2}$ efflux, with the exceptions being freezing conditions early or late in the season or on some very dry 
days in 1999. No soil moisture measurements were made yet in 1997. Starting in 1999, water-content reflectometers monitored soil water content continuously. In addition, the gravimetric water content of moss and upper soil layers including litter layer, organic i.e. humus layer and $0-10 \mathrm{~cm}$ of the uppermost mineral soil was determined on days for measuring soil efflux (Table 1). Water content of moss was monitored so that the contribution of dark respiration of moss layer to the surface soil $\mathrm{CO}_{2}$ efflux could be estimated.

Tensiometer plots were situated on gentle slopes and small depressions next to Plot 1 in the stand in which Plot 2 was also located, and on flat terrain next to Plot 3 in the younger stand. Tensiometers were located some 2 to 3 meters from the boundaries of soil $\mathrm{CO}_{2}$ efflux plots to avoid unnecessary trampling inside the plots because of maintenance and measurements. Two to three tensiometers were placed at depths of 5, 10, 20 and $30 \mathrm{~cm}$ of mineral soil, i.e. to the depth of the main rooting zone. Precipitation sensors connected to the weather station were placed in the vicinity of tensiometers next to Plots 1 and 3 as well. To convert tensiometer readings to values for soil water content, the water retention curve was determined in the laboratory in desorption for depths of 5-30 cm with a tension chamber and a pressure plate apparatus (Klute, 1986). Soil water retention ranged, on average, from $0.55 \mathrm{~m}^{3} \mathrm{~m}^{-3}$ at saturation $(-0.1 \mathrm{kPa})$ to $0.25 \mathrm{~m}^{3} \mathrm{~m}^{-3}$ at $-10 \mathrm{kPa}$ and $0.07 \mathrm{~m}^{3} \mathrm{~m}^{-3}$ at the wilting point $(-1554 \mathrm{kPa})$. Water-content reflectometers were installed close to Plot 1 and placed horizontally at mineral soil depths of 5,15 , and $25 \mathrm{~cm}$. There was also a sensor in the surface layer, which consisted of both the organic layer and the topmost mineral soil. Velocity of the electromagnetic waves along the $30-\mathrm{cm}$ sensor rods was converted to volumetric water content using equations based on soil-specific calibration (Appendix A).

Differences in water content between measurement depths in mineral soil were small, but at all times of measurement the surface layer was wetter than the mineral soil layers (Table 1). Water-content reflectometers were found to give about $0.10 \mathrm{~m}^{3} \mathrm{~m}^{-3}$ lower values than the comparable values calculated from tensiometer readings with the help of a cubic model of water retention. This was probably due to small stones, which were too big to be included in core samples for water retention analysis but were abundant in the soil. Still, the seasonal patterns were similar, which resulted in a good correlation between the two methods (Spearman's rho $=0.89-0.97$ for different depths, $P<0.001$ ).

Temporal variation of soil moisture measured next to Plot 1 was similar to variation measured next to Plot 3: Soil matric potential measurements made next to Plot 1 correlated strongly with measurements made next to Plot 3 . For the year of great fluctuations in soil moisture,1999, Spearman's rho was 0.97 and Pearson correlation $0.97(p<0.001, n=45)$ between soil matric potential averaged for soil column between depths 5 and $30 \mathrm{~cm}$ on soil $\mathrm{CO}_{2}$ efflux measuring days. Correspondingly, variation in average soil matric potential next to Plot 3 explained $97 \%$ of the temporal variation next to Plot 1 in 1999 according to a linear regression analysis $(p<0.001, n=45)$.

Needle litter was collected in netted buckets with a surface area of $0.15 \mathrm{~m}^{2}$ at eight locations in the study area monthly or bimonthly, dried in the oven at $105^{\circ} \mathrm{C}$ for $24 \mathrm{~h}$ and weighted. In addition, the diameter growth of six pine trees (representing median of the diameter distribution of the study area) was monitored with continuously recording bands around tree trunks starting in 1999.

\subsection{Modelling and statistical analyses}

Different models of soil temperature and moisture response were fitted to the data and data subsets (Table 2). Because soil temperature recorded at the weather station was found to be as good a predictor as temperature measured adjacent to each collar, it was therefore used in model analyses. For analyses containing observations from 1997, however, temperature readings next to the collars were used because of the discontinuity in weather station measurements in 1997. In the efflux data for late summer of 1997, sudden extreme values of 4 to $6 \mathrm{~g} \mathrm{CO}_{2} \mathrm{~m}^{-2} \mathrm{~h}^{-1}$ from a measurement point were excluded from the plot averages to allow assessment of the effect of temperature on soil $\mathrm{CO}_{2}$ efflux. These observations of extreme efflux persisted from the morning to the afternoon and from a day to another regardless of repeated extra measurements and testing of equipment for measurement errors. They were interpreted to be caused most likely by a rapid increase in fungal activity as suggested by Savage and Davidson (2003) in a comparable situation in a temperate forest. Similar sudden increases were found to precede appearances of fungal fruit bodies inside some collars at our site in the following years. Other biological factors cannot, however, be excluded. The complete 6-month data from the two later years, 1998 and 1999, were used for further multivariable analysis, because the data of 1997 lacked soil moisture measurements.

The temperature response of $\mathrm{CO}_{2}$ efflux was modelled as an exponential function (as in Anderson, 1973; Davidson et al., 1998, Niinistö et al., 2004). Natural logarithmic transformation of $\mathrm{CO}_{2}$ efflux (LnFlx) was used for both the linear and quadratic models tested because it linearized the temperature response and corrected for heteroscedasticity as noted previously (Howard and Howard, 1993; Wang et al., 2003). Heteroscedasticity was observed when residuals of temperature response of untransformed $\mathrm{CO}_{2}$ efflux increased greatly as temperature increased but natural logarithmic transformation of $\mathrm{CO}_{2}$ efflux corrected this. A linear model was formulated as LnFlux $=b_{0}+b_{1} \times T_{\text {soil }}$ (which is equivalent to Flux $=e^{b_{0}+b_{1} \times T_{\text {soil }}}$ ) and a quadratic model as LnFlux $=b_{0}+b_{1} \times T_{\text {soil }}+b_{2} \times T_{\text {soil }}^{2}$, in which $T_{\text {soil }}$ is soil temperature and $b_{0}, b_{1}, b_{2}$ freely determined parameters. For comparison purposes, the Lloyd and Taylor (1994) version of the Arrhenius function, with three freely determined parameters $\left(A, E_{0}, T_{0}\right)$, was fitted to the pooled three-year data. It 
Table 1. Measurements of water potential and water content of soil on days when soil $\mathrm{CO}_{2}$ efflux was measured.

\begin{tabular}{|c|c|c|c|c|c|c|c|c|}
\hline \multirow{2}{*}{$\begin{array}{l}\text { Variable and } \\
\text { Method }\end{array}$} & \multicolumn{4}{|l|}{ Make and } & \multicolumn{4}{|c|}{ Range of area mean } \\
\hline & Manufacturer/ Method & Unit & Frequency & Time period & Min & Mean & Max & Soil layer \\
\hline \multicolumn{9}{|l|}{ Soil water potential } \\
\hline \multirow[t]{2}{*}{ Tensiometers } & Soil Moisture Inc., USA & $\mathrm{kPa}$ & Once/ & 15 May-29 Sep 1998 & -11 & -7 & -4 & $5-30 \mathrm{~cm}$ in mineral soil \\
\hline & & & twice a day & 25 May-12 Oct 1999 & -52 & -24 & -4 & $5-30 \mathrm{~cm}$ in mineral soil \\
\hline \multicolumn{9}{|l|}{ Soil water content } \\
\hline \multirow[t]{2}{*}{ Reflectometers } & CS615 sensors & $\mathrm{m}^{3} \mathrm{~m}^{-3}$ & Every & 26 Apr-19 Oct 1999 & 0.18 & 0.25 & 0.37 & Surface (organic+mineral) \\
\hline & $\begin{array}{l}\text { CR10X datalogger, } \\
\text { Campbell Scientific, } \\
\text { Shepshed, LE, UK }\end{array}$ & & $15 \mathrm{~min}$ & & 0.07 & 0.15 & 0.28 & $2-28 \mathrm{~cm}$ in mineral soil \\
\hline \multirow[t]{7}{*}{ Gravimetric } & Dry mass determined & $\%$ & Once a & 15 May-22 Oct 1998 & 181 & 451 & 946 & Litter (Oi) \\
\hline & after in oven at $105^{\circ} \mathrm{C}$ & & day & & 147 & 260 & 456 & Organic $(\mathrm{Oe}+\mathrm{Oa})$ \\
\hline & for $24 \mathrm{~h}$ & & & & 29 & 38 & 53 & $0-10 \mathrm{~cm}$ in mineral soil \\
\hline & & & & 1 Jun-19 Oct 1999 & 61 & 287 & 756 & Moss (living moss) \\
\hline & & & & & 68 & 228 & 758 & Litter (Oi) \\
\hline & & & & & 35 & 99 & 241 & Organic $(\mathrm{Oe}+\mathrm{Oa})$ \\
\hline & & & & & 9 & 23 & 46 & $0-10 \mathrm{~cm}$ in mineral soil \\
\hline
\end{tabular}

was formulated as Flux $=A \times e^{-\mathrm{E}_{0} /\left(T_{\text {soil }}+273.15-T_{0}\right)}(\mathrm{Eq} .10 \mathrm{in}$ Lloyd and Taylor, 1994). In multivariable analysis, different factors were tested as predictors of logarithmic transformation of soil $\mathrm{CO}_{2}$ efflux (Table 2). Degree days i.e. heat sum was calculated according to the guidelines of the Finnish Meteorological Institute by cumulatively totalling those parts of the daily air temperature that exceeded a threshold of $5^{\circ} \mathrm{C}$ which is used to define the start of the thermal growing season in Finland. Summing up started when daily air temperatures had continuously exceeded $5^{\circ} \mathrm{C}$ for five days in spring and ended when daily temperatures had been below the threshold temperature for five consecutive days in autumn.

Regression and correlation analyses were carried out with SPSS 16.0 software (SPSS Inc, Chicago, USA). Differences in regression coefficients and intercepts between linear regressions were tested with Student's t-test (Zar, 1999). To correct the bias caused by the logarithmic transformation, half of the total residual variance was added to the logarithmic prediction for model evaluation. Root Mean Squared Errors and Akaike's Information Criterion were used for comparing models and tolerance was used to assess multicollinearity.

\section{Results}

\subsection{Temporal pattern and range of soil $\mathrm{CO}_{2}$ efflux}

Soil $\mathrm{CO}_{2}$ efflux peaked in July-August, in general, following changes in soil temperature (Fig. 1a, b). However, a drop in July 1999 on 20th and 22nd appeared to be related to a steep decline in soil water content at the same time (Fig. 1b, d). In general, plot averages ranged from 0.04 to $0.90 \mathrm{~g} \mathrm{CO}_{2} \mathrm{~m}^{-2} \mathrm{~h}^{-1}$ during the snow-free period in 1997 ,
1998 and 1999. The minimum for individual point observations was $0.02 \mathrm{~g} \mathrm{CO}_{2} \mathrm{~m}^{-2} \mathrm{~h}^{-1}$ in the freezing conditions of May 1999, and the maximum was $2.25 \mathrm{~g} \mathrm{CO}_{2} \mathrm{~m}^{-2} \mathrm{~h}^{-1}$, which was measured after thunderstorms in July 1997.

Sudden extreme values of 4 to $6 \mathrm{~g} \mathrm{CO}_{2} \mathrm{~m}^{-2} \mathrm{~h}^{-1}$ from a measurement point were found in August-September 1997 that were possibly caused by a rapid increase in fungal respiration although other biological factors cannot be excluded. In the following years, similar but less extreme increases were observed in individual points in August-October that resulted in fungal fruit bodies found inside measurement collars (Fig. 2).

Winter fluxes ranged from a mean of $0.044 \mathrm{~g} \mathrm{CO}_{2} \mathrm{~m}^{-2} \mathrm{~h}^{-1}$ in February 1999 to $0.134 \mathrm{~g} \mathrm{CO}_{2} \mathrm{~m}^{-2} \mathrm{~h}^{-1}$ in March 2000, the average being $0.06 \mathrm{~g} \mathrm{CO}_{2} \mathrm{~m}^{-2} \mathrm{~h}^{-1}$ for 1999 and $0.12 \mathrm{~g} \mathrm{CO}_{2} \mathrm{~m}^{-2} \mathrm{~h}^{-1}$ for 2000. The snow layer decreased in depth from February to April and became more compacted and layered with icier streaks, trapping $\mathrm{CO}_{2}$ efflux from the soil more effectively. $\mathrm{CO}_{2}$ concentration close to the soil surface varied with the characteristics of the snow pack: Under well-aerated snow cover, in February 1999 it was 400$700 \mathrm{ppm}$, whereas under the deep and layered snow of March 2000 it was, on average, 1050 ppm (Fig. 3).

\subsection{Response to temperature and seasonality of the temperature response}

According to a linear regression model for the combined data for the snow-free periods of years 1997, 1998 and 1999, variation in soil temperature $\left(T_{\text {soil }}\right)$ next to the collars explained $67 \%$ of the variation in the natural logarithm of soil $\mathrm{CO}_{2}$ efflux (LnFlux) (Fig. 4). A quadratic LnFlux model captured low efflux rates at the lowest soil temperatures better than the linear LnFlux model and did not overestimate efflux at the highest temperatures as the linear model did (Fig. 4). 


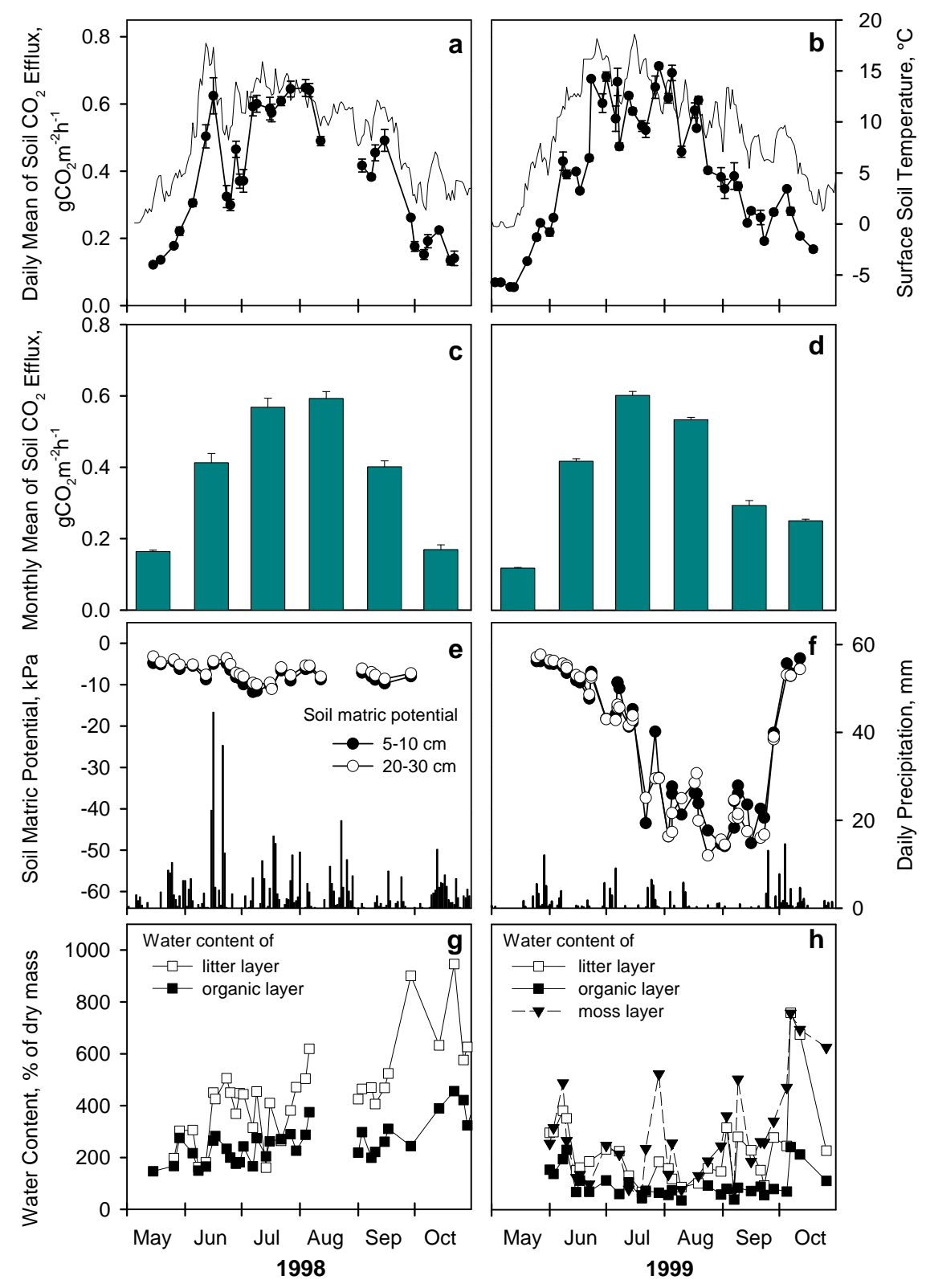

Fig. 1. (a, b) Daily means of soil $\mathrm{CO}_{2}$ efflux in May-October 1998 (a) and 1999 (b) shown with black circles, standard error bars presenting variation between three plots. Each plot represents an average of 10 measurement points. Soil temperature at $1-2 \mathrm{~cm}$ in the organic i.e. humus layer is depicted with solid black line. (c, d) Monthly means of soil $\mathrm{CO}_{2}$ efflux in May-October 1998 and 1999, standard error bars presenting variation between three plots. (e, f) Average soil matric potential at 5-10 cm depth (open circles) and at 20-30 cm depth (black circles) and daily precipitation depicted with black bars in 1998 (e) and 1999 (f). (g, h) Gravimetric water content of litter (open squares), organic i.e. humus (black squares) and moss layer (triangles) in 1998 (e) and 1999 (f).

This resulted in a significantly smaller root mean square error (RMSE, by about $20 \%$ ) and greater coefficient of variation $\left(R^{2}=0.76\right.$ for 1997-1999 in Fig. 4, 0.82 for 1998-1999 in Table 2) than the linear model. The further developed version of the Arrhenius function, the so-called Lloyd \& Taylor model (Lloyd and Taylor, 1994), also performed satisfactorily $\left(R^{2}=0.64\right.$, Fig. 4$)$, with some heteroscedasticity in residuals.
Monthly averages of soil $\mathrm{CO}_{2}$ efflux observations in 1997-1999 ranged from $0.14 \mathrm{~g} \mathrm{CO}_{2} \mathrm{~m}^{-2} \mathrm{~h}^{-1}$ for May to $0.58 \mathrm{~g} \mathrm{CO}_{2} \mathrm{~m}^{-2} \mathrm{~h}^{-1}$ for August (Fig. 5a). At a given temperature, soil $\mathrm{CO}_{2}$ efflux was higher later in the snowfree period than in spring and early summer (Fig. 5a). Based on month-specific temperature response models for pooled 1997-1999 data, regression coefficients for temperature, and thus approximations for $Q_{10}$ values, 


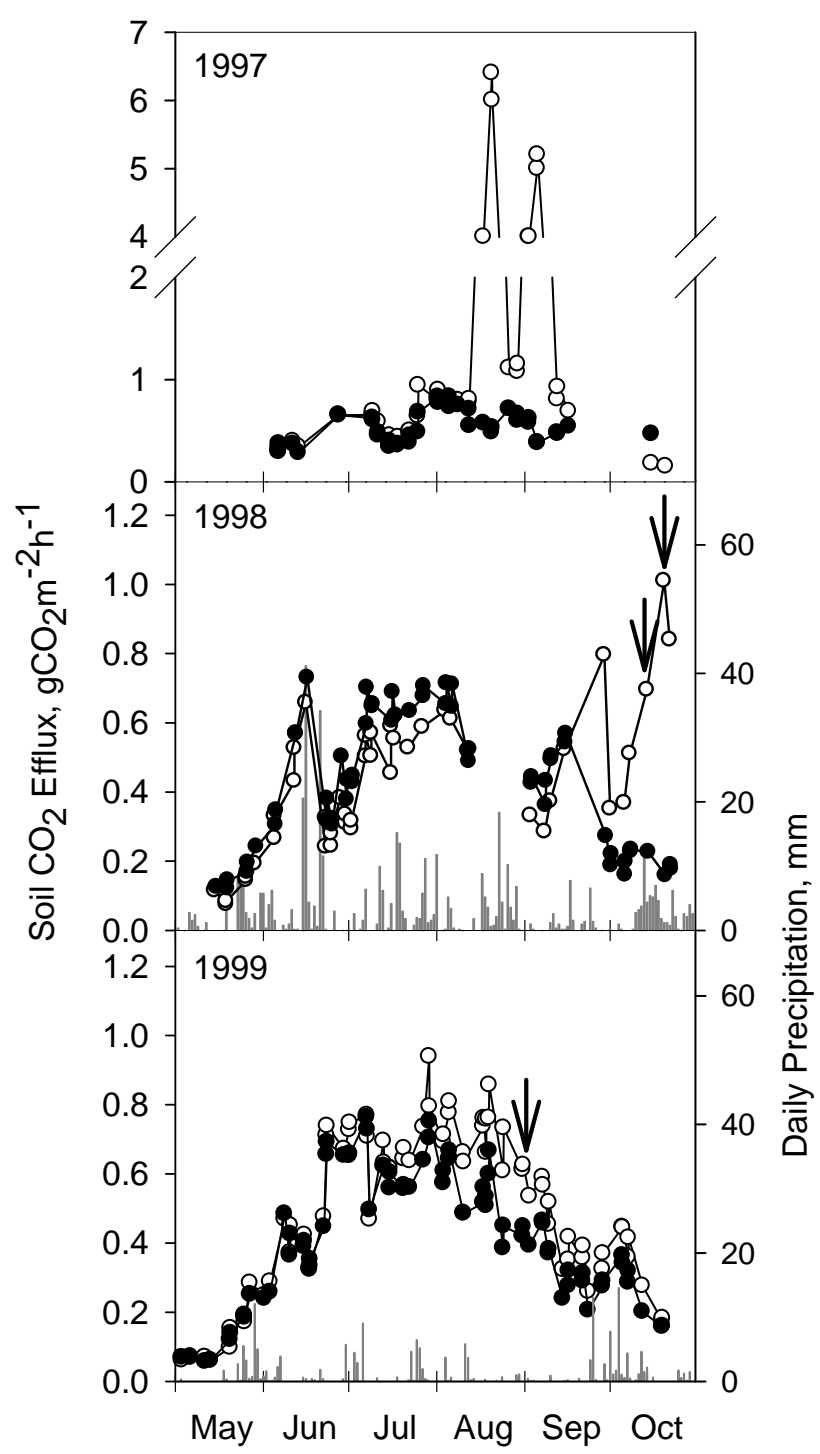

Fig. 2. Three examples of sudden increases in the level of soil $\mathrm{CO}_{2}$ efflux from a point. Plot averages of 9-10 points are represented by black circles and efflux from an individual point by open circles, one or two measurements per measuring day. Daily precipitation is depicted with grey bars. Arrows point at occasions when a fungal fruit body was found in a collar and removed.

decreased with increasing average soil temperature (Fig. 5b, c). The month of May had the lowest predicted $\mathrm{CO}_{2}$ efflux, $0.24 \mathrm{~g} \mathrm{CO}_{2} \mathrm{~m}^{-2} \mathrm{~h}^{-1}$, at $10^{\circ} \mathrm{C}$ and August the highest, $0.47 \mathrm{~g} \mathrm{CO}_{2} \mathrm{~m}^{-2} \mathrm{~h}^{-1}$.

Efflux observations in July showed no clear response to soil temperature at the time of measurement: no response to temperature in pooled three-year data or in 1998 and 1999 separately, but a weak positive response to temperature in July $1997\left(R^{2}=0.15, p=0.013, n=41\right)$. Correspondingly, for 12 of the 15 collars that remained the same for the three-year period, analyses of the efflux of
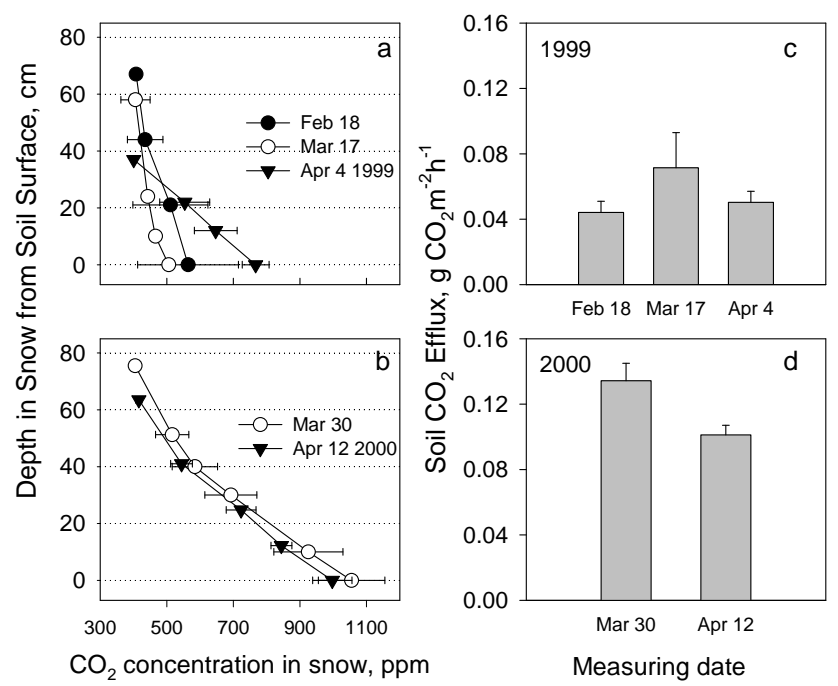

Fig. 3. (a, b) Concentration of $\mathrm{CO}_{2}$ in snow (s.e. as error bars, $n=2-4$ ). The top-most symbols represent average concentration in the top $2 \mathrm{~cm}$ of snow. (c, d) Soil $\mathrm{CO}_{2}$ efflux in winter in 1999 (c) and $2000(d)$, standard error bars presenting variation between two plots measured, $n=3$ per plot.

individual measurement collars revealed no temperature response in July and a weak response for 3 collars (only with soil temperature $\leq 20^{\circ} \mathrm{C}$ ). The $24 \mathrm{~h}$ and $48 \mathrm{~h}$ averages for soil or air temperature failed to explain the variation in soil $\mathrm{CO}_{2}$ efflux in July 1999.

\subsection{Response to soil moisture}

A decrease in soil moisture was correlated with an increase in soil $\mathrm{CO}_{2}$ efflux during the first three months of the snow-free period in both years (Spearman's rho between LnFlux and soil water content was -0.68 in May-July 1998 and -0.80 in May-July 1999 compared to -0.51 and -0.73 between soil temperature and soil water content in May-July 1998 and in May-July 1999, respectively, $p<0.001)$. There was a strong negative correlation between soil water content and time in May-July. Soil water content decreased with time after the maximum water content in May, after the snow-melt (Spearman's rho between soil water content and Julian Day was -0.80 in 1998 and -0.94 in $1999, P<0.001)$. A similar strong, but positive correlation was found between soil $\mathrm{CO}_{2}$ efflux and time (Spearman's rho between LnFlux and Julian Day was +0.81 in May-July 1998 and +0.87 in May-July 1999, $P<0.001)$. There was no clear correlation between soil $\mathrm{CO}_{2}$ efflux and soil moisture during the latter part of the snow-free period, August-October, in either year.

When observations for which the soil matric potential was smaller than $-10 \mathrm{kPa}$ were selected, soil $\mathrm{CO}_{2}$ efflux increased linearly with increasing soil moisture. The negative effect of dry conditions was notable in 1999. For instance, soil $\mathrm{CO}_{2}$ efflux at $10^{\circ} \mathrm{C}$ was one third smaller in 


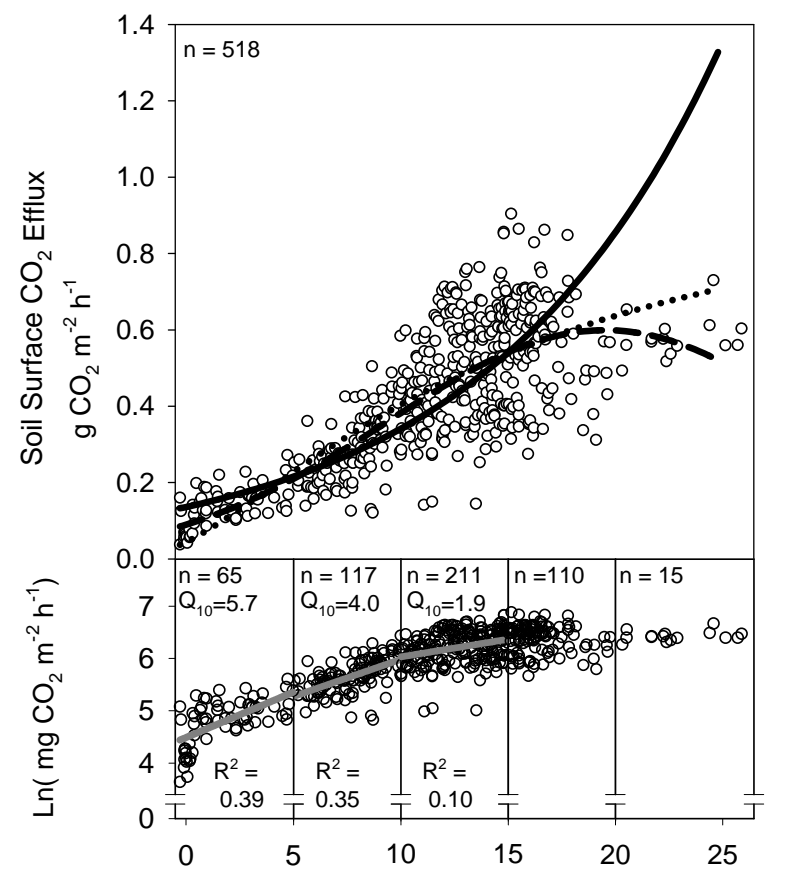

Soil temperature $\left(\mathrm{T}_{\text {soil }}\right)$ at $1-2 \mathrm{~cm}$ in the organic layer $\left({ }^{\circ} \mathrm{C}\right)$

Linear model: LnFlux $=4.855+0.092^{*}$ Tsoil $\quad Q_{10}=2.5 \quad R^{2}=0.67$ Quadratic model: LnFlux $=4.454+0.195^{*}$ Tsoil- $-0.005^{*}$ Tsoil $^{2} R^{2}=0.76$ Lloyd \&Taylor: Flux $\left(\right.$ umolm $\left.^{-2} \mathrm{~s}^{-1}\right)=9.24^{*} \exp (-19.52 /($ Tsoil $+273.15-267.58)) \mathrm{R}^{2}=0.64$

Fig. 4. Modelled temperature response of pooled three-year data on soil $\mathrm{CO}_{2}$ efflux (1997-1999). Solid lines illustrate linear regression model for natural logarithm of soil $\mathrm{CO}_{2}$ efflux, LnFlux and a dashed line indicates quadratic regression model for LnFlux. A dotted line indicates the Lloyd \& Taylor (1994) version of the Arrhenius function fitted for soil $\mathrm{CO}_{2}$ efflux observation data. Observations are plot averages. Soil temperature $\left(T_{\text {soil }}\right)$ was measured next to collars with hand-held probe. Equations for the models in the upper graph are given below the figure. $Q_{10}$ of the linear regressions was calculated as $Q_{10}=e^{10 \times b_{1}}, b_{1}$ from the temperature response model formulated as LnFlux $=b_{0}+b_{1} \times T_{\text {soil }}$. All relations for which $R^{2}$ is given were statistically significant, as were regression coefficients and constants $(p<0.001)$.

September 1999 (soil water content $\theta_{\text {mean }}=0.08 \pm 0.018$ (s.d.) $\left.\mathrm{m}^{3} \mathrm{~m}^{-3}\right)$ than in September $1998\left(\theta_{\text {mean }}=0.19 \pm 0.016\right.$ (s.d.) $\mathrm{m}^{3} \mathrm{~m}^{-3}$, estimated from matric potential measurements) although mean soil temperature during the measurements was the same and the range of temperatures was similar (Fig. 1c, d).

Accordingly, for observations for which soil moisture was below $0.10 \mathrm{~m}^{3} \mathrm{~m}^{-3}$ in 1999, mainly in August and September, variation in water content of mineral soil alone explained $64 \%$ of the variation in LnFlux $(P<0.001, n=89)$; and addition of soil temperature added only some $8 \%$ more to the explained variation. Correspondingly, the month-specific temperature models based on 3-year data overestimated efflux in the driest conditions, i.e. when soil water content was below $0.08 \mathrm{~m}^{3} \mathrm{~m}^{-3}$ in August and September 1999.

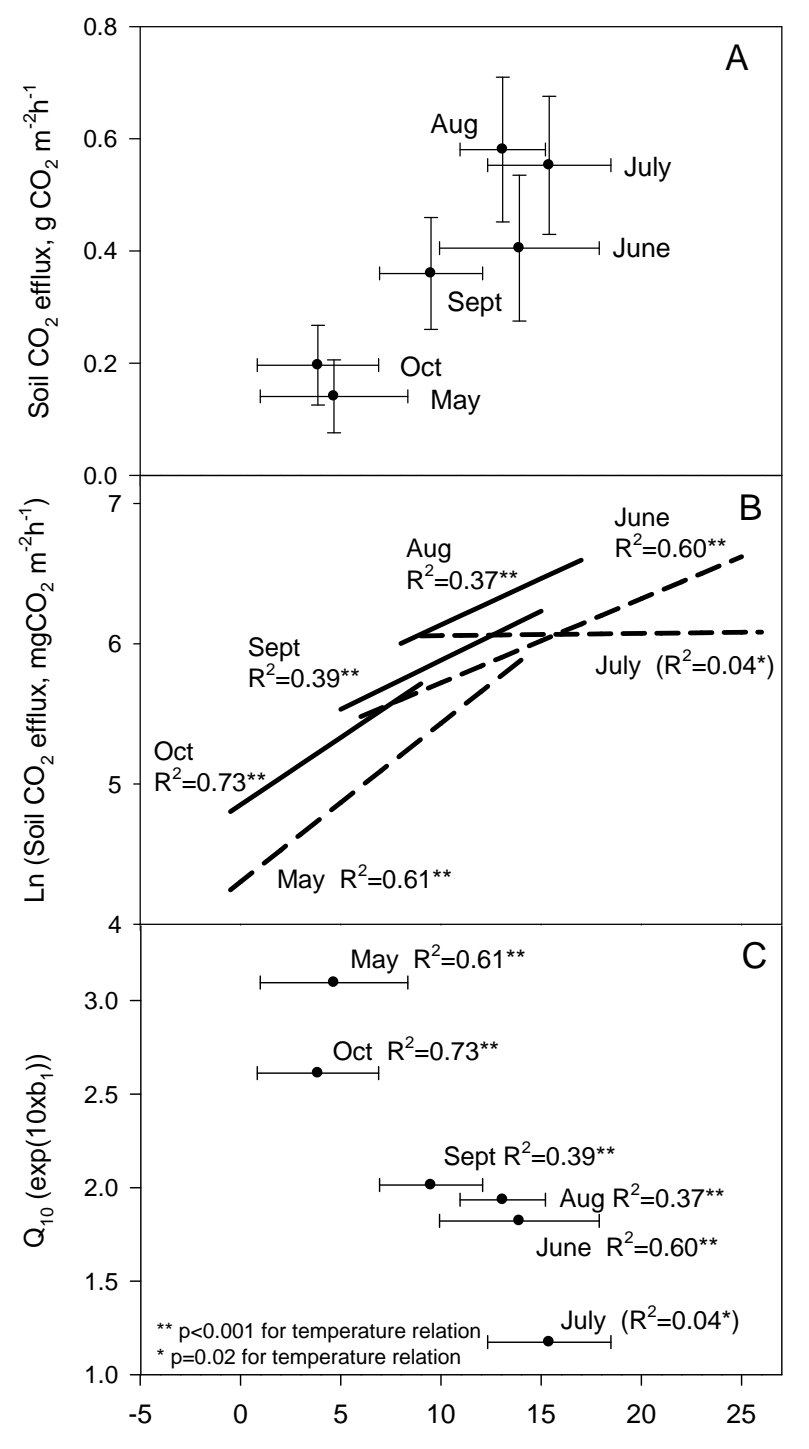

$\mathrm{T}_{\text {soil }}$ (mean temperature at the moment of flux measurements)

Fig. 5. (A) Means for soil $\mathrm{CO}_{2}$ efflux and soil temperature for monthly subsets of three-year data (1997-1999). Error bars represent standard deviation. Number of observations varied from 50 (May) to 126 (July). (B) Month-specific temperature-response models based on three-year data (1997-1999). Models formulated as LnFlux $=b_{0}+b_{1} \times T_{\text {soil }}$. (C) $Q_{10}$ calculated as $Q_{10}=e^{10 \times b_{1}}, b_{1}$ from the temperature-response model formulated as LnFlux $=b_{0}+b_{1} \times T_{\text {soil }}$. Constants, $b_{0}$ 's were 4.302 (May), 5.121 (Jun), (6.042 (Jul)), 5.475 (Aug), 5.182 (Sep), and 4.851 (Oct). Regression coefficients, $b_{1}$ 's, did not differ statistically significantly between May and October, but the constants did $(p<0.001)$. The same was true for comparisons between June, August and September.

However, residuals calculated by subtracting efflux predicted by the month-specific temperature models from observed efflux did not, in general, show any trend with soil water content for the entire range of soil moisture for 1998 
and 1999. Variation in mineral soil moisture did not explain the variation in $\mathrm{CO}_{2}$ efflux in July 1998 or July $1999(n=38$ (1998) and 47 (1999)), but there was some positive correlation between LnFlux and gravimetric water content of moss and the organic layer measured at the time of flux measurements in July of the dry year 1999 (Spearman's rho 0.70 and $0.45, p<0.001$ and $<0.02, n=29$ ).

\subsection{Multiple regression models and their evaluation}

In multiple regression models for the entire snow-free period, soil temperature was the dominant predictor of $\mathrm{ln}$ transformed soil $\mathrm{CO}_{2}$ efflux (LnFlux). Addition of the square of soil temperature markedly improved the model (Table 2). Multiple regression models were based on pooled data for the years 1998 and 1999 because the data for 1997 lacked observations on soil water content.

Degree days, i.e. cumulative sum of daily air temperatures exceeding $5^{\circ} \mathrm{C}$ or its alternatives day of year and degree days divided or multiplied by day of year, were better auxiliary predictors of LnFlux than soil moisture was (Table 2). A multiple regression model with soil temperature, degree days as an index of seasonality and their squares as predictors was found to have a good fit for the entire snow-free period, especially due to its evenly distributed residuals with respect to measured efflux. Inclusion of the square of degree days was justified on the basis of the decrease in RMSE, but soil moisture was not found to be a significant predictor in the step-wise regression analysis that had soil temperature, degree days and their squares to chose from in addition to soil moisture. Inclusion of an interaction variable of soil temperature $x$ degree days was statistically supported at 0.05 level, with further justification from the comparison of Akaike's Information Criteria. However, its inclusion was not supported by a notable decrease in RMSE and the effect of its inclusion to the coefficient of determination was small $\left(\Delta R^{2}=0.002\right)$. Residuals for the model with soil temperature, degree days and their squares did not vary with soil moisture.

The performance of different regression models was compared to independent sets of soil $\mathrm{CO}_{2}$ efflux data collected on two sites, Huhus and Mekrijärvi, in the year 2000. The chosen LnFlux models based on pooled 1998 and 1999 data measured in Huhus, a simple linear temperature model, a quadratic temperature model, with or without soil moisture, and a combined quadratic temperature and quadratic degree days model (Table 2) were used to predict efflux on Plot 1 in Huhus. In addition, the quadratic temperature models with and without degree days were used to estimate the efflux on a plot of identical design in another young pine stand in nearby Mekrijärvi.

In general, models overestimated the efflux at low temperatures, i.e. in May and October at both sites. The relatively greatest single overestimation, up to $110-140 \%$ by models without degree days as a seasonality index and approximately $60 \%$ by combined temperature and degree days model, occurred on a typical spring day in May: air and surface soil temperatures were clearly above $10^{\circ} \mathrm{C}$ but efflux was still relatively low, $0.21 \mathrm{~g} \mathrm{CO}_{2} \mathrm{~m}^{-2} \mathrm{~h}^{-1}$. The greatest consistent underestimation occurred in Huhus during the peak season in August: an average of $35 \%$ by the linear temperature model, about $25-30 \%$ by the quadratic temperature model with or without soil moisture and an average of $17 \%$ by the quadratic temperature model with the degree days (Fig. 6). For Mekrijärvi, the greatest underestimations with the quadratic temperature and degree days model were also made for two days of peak flux that occurred there in July.

On the whole, the quadratic temperature and degree days model performed best with a high correlation between measured and predicted flux both in Huhus $\left(R^{2}=0.90, p<\right.$ $0.001)$ and in Mekrijärvi $\left(R^{2}=0.89, p<0.001\right)$. Inclusion of degree days in the temperature model resulted in a notable decrease in average difference between measured and predicted flux for both sites (Fig. 7). It especially improved predictions at low temperatures in May but also, in general, in June to September, although not in October (Fig. 6).

For Huhus, the difference between measured and predicted was, on average, $14 \%$ of the average $\left(0.45 \mathrm{~g} \mathrm{CO}_{2} \mathrm{~m}^{-2} \mathrm{~h}^{-1}\right)$ for the measured flux using the quadratic temperature model with degree days. There was a small bias connected with observations from the three days of peak flux, July 18 and August 1 and 15. In comparison, the linear and quadratic temperature models gave unbiased estimates; i.e. regression intercepts were not significantly $(p<0.001)$ different from 0 nor did the regression coefficients differ significantly from 1 (1:1 line), but the correlation between measured and predicted efflux was notably smaller $\left(R^{2}=0.56\right.$ and 0.61 , $p<0.001)$. Predictions made by the quadratic soil temperature model with moisture differed slightly from the 1:1 line of predicted versus measured efflux, indicating small bias.

Despite a small bias, a quadratic temperature and degree days also gave good predictions for the nearby Scots pine site in Mekrijärvi; the difference between measured and predicted was, on average, $12 \%$ of the average $\left(0.47 \mathrm{~g} \mathrm{CO}_{2} \mathrm{~m}^{-2} \mathrm{~h}^{-1}\right)$ for the measured flux. Exclusion of a measuring point with a burst of efflux possibly related to fungal growth starting in August, at maximum four-fold compared to the plot mean, improved the fit.

\subsection{Estimates of annual efflux}

Different models of LnFlux (Table 2) resulted in similar cumulative estimates of soil $\mathrm{CO}_{2}$ efflux. For the six snow-free months in 1998, the estimate predicted with the quadratic temperature and continuous weather data was $1509 \mathrm{~g} \mathrm{CO}_{2} \mathrm{~m}^{-2}$ whereas the estimate by the quadratic temperature and degree days model was not significantly greater (a $3 \%$ difference). For the six snow-free months of 1999, estimates with the quadratic temperature and degree days model and the quadratic temperature and soil moisture model were within $1 \%$ of the estimate of $1533 \mathrm{~g} \mathrm{CO}_{2} \mathrm{~m}^{-2}$ by 
Table 2. Comparison of multiple regression models for the pooled 1998 and 1999 data.

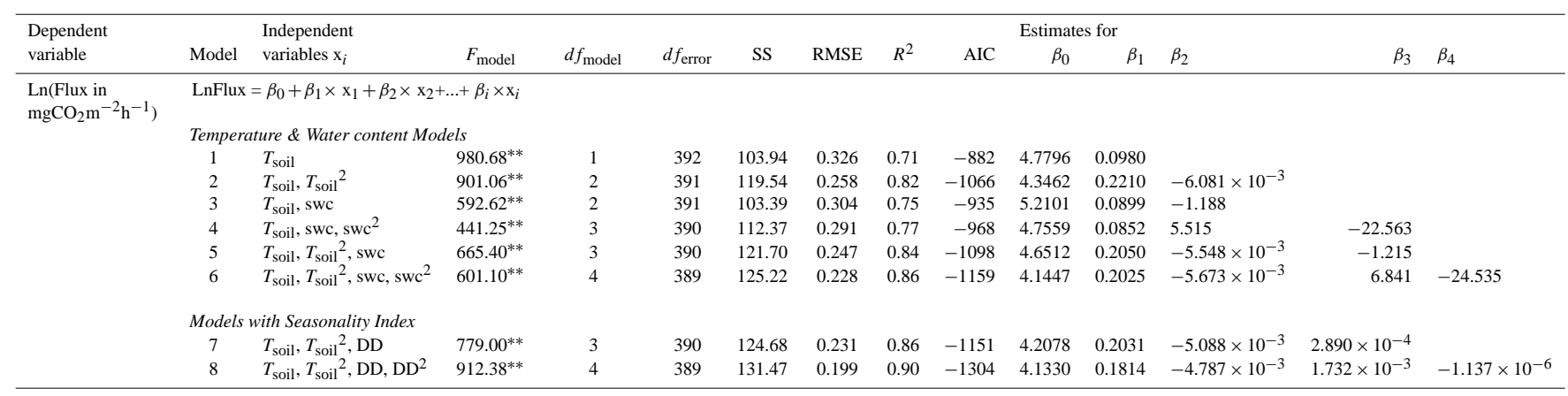

Independent variables: soil temperature at $1-2 \mathrm{~cm}$ in the organic i.e. humus layer $\left(T_{\mathrm{soil}}\right)$, water content of the upper $30 \mathrm{~cm}$ of mineral soil (swc), degree days i.e. cumulative sum of daily air temperatures exceeding $5^{\circ} \mathrm{C}$ (DD). Variables also tested included mineral soil matric potential, water content of moss, litter or organic layer, plot, time of measurements, day of year, month, interaction variables such as $T_{\text {soil }} \times \mathrm{swc}$, degree days/day of the year and $T_{\text {soil }} \times$ degree days (models not shown). RMSE $=$ a square root of mean squared error, AIC $=$ Akaike's Information Criterion. $* *$ denotes statistical significance at the 0.001 risk level.

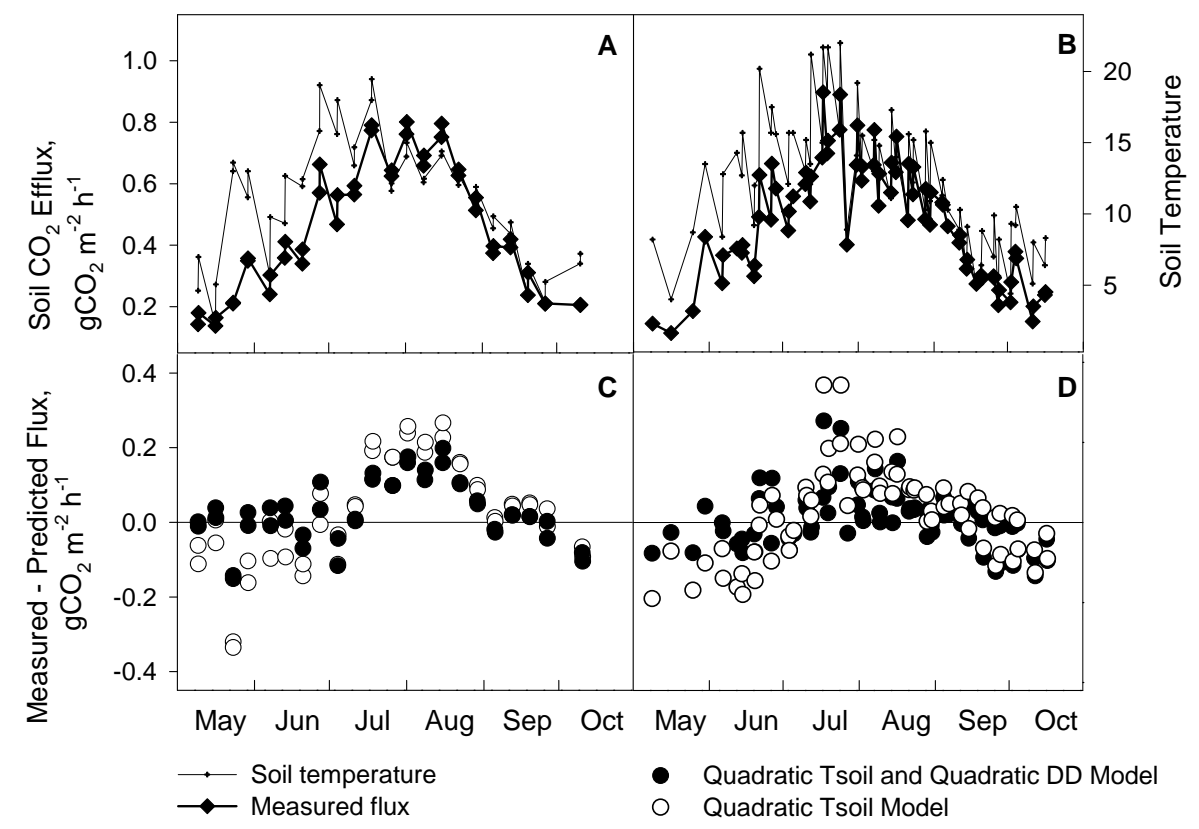

Fig. 6. Model evaluation: Soil $\mathrm{CO}_{2}$ efflux and soil temperature at the time of measurements in $2000((\mathbf{A})$ in Huhus and (B) in Mekrijärvi) and difference between measured and predicted efflux $\left((\mathbf{C})\right.$ in Huhus and (D) in Mekrijärvi). Models formulated as LnFlux $=b_{0}+b_{1} \times T_{\text {soil }}+$ $b_{2} \times T_{\text {soil }}^{2}$ and LnFlux $=b_{0}+b_{1} \times T_{\text {soil }}+b_{2} \times T_{\text {soil }}^{2}+b_{3} \times$ degree_days $+b_{4} \times$ degree_days ${ }^{2}$. Note: Degree days (DD) $=$ Cumulative sum of daily air temperatures exceeding $5^{\circ} \mathrm{C}$. See Table 2 for values of regression coefficients.

the quadratic temperature model. The difference in the estimated sum of soil $\mathrm{CO}_{2}$ efflux between the snow-free periods of 1998 and 1999 was small, $1-1.5 \%$. The period from June to August represented 50-60\% of the annual estimate.

Accumulated efflux during winter was calculated using the average of the winter measurements in February-April 1999 for 1998 and the average of the measurements in MarchApril 2000 for 1999. The six winter months, from November to April, thus represented, on average, $14 \%$ of the annual soil $\mathrm{CO}_{2}$ efflux for the snow-free period of 1998 combined with the winter 1998-1999 and 25\% for the snow-free period of 1999 combined with the winter 1999-2000. The greater efflux in winter 1999-2000 compared to the winter before resulted in a $15 \%$ greater annual sum for the latter 12 month period (i.e. $2050 \mathrm{~g} \mathrm{CO}_{2} \mathrm{~m}^{-2} \mathrm{a}^{-1}$ ). The efflux of the latter winter was twice that of the previous winter which had a greater effect on the estimate of the annual soil $\mathrm{CO}_{2}$ efflux than a correction of $+15 \%$ for model underestimation during peak efflux (in July-August) would have had. 


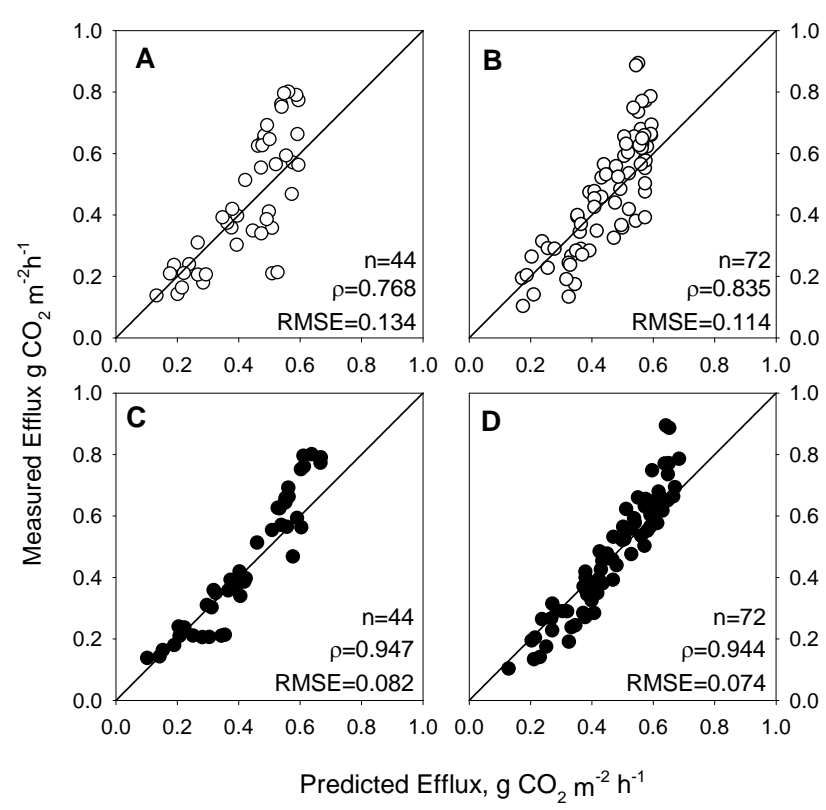

Fig. 7. Predicted versus measured efflux in evaluation data in 2000. (A) Predicted efflux in Huhus in 2000 with the quadratic soil temperature model. (B) Predicted efflux in Mekrijärvi in 2000 with the quadratic soil temperature model. (C) Predicted efflux in Huhus in 2000 with the quadratic soil temperature and degree days model. (D) Predicted efflux in Mekrijärvi in 2000 with the quadratic soil temperature and degree days model. Models formulated as LnFlux $=b_{0}+b_{1} \times T_{\text {soil }}+b_{2} \times T_{\text {soil }}^{2}$ and LnFlux $=b_{0}+$ $b_{1} \times T_{\text {soil }}+b_{2} \times T_{\text {soil }}^{2}+b_{3} \times$ degree_days $+b_{4} \times$ degree_days ${ }^{2}$.

\section{Discussion}

\subsection{Range of soil $\mathrm{CO}_{2}$ efflux and annual estimates}

The temporal range of plot averages of soil $\mathrm{CO}_{2}$ efflux measured here, 0.04 to $0.90 \mathrm{~g} \mathrm{CO}_{2} \mathrm{~m}^{-2} \mathrm{~h}^{-1}$, was within the range reported for boreal Scots pine forests (e.g. Högberg et al., 2001; Pumpanen et al., 2003a). Our annual estimates, ranging from 1750 to $2050 \mathrm{~g} \mathrm{CO}_{2} \mathrm{~m}^{-2}$ for 1998 and 1999 , also corresponded to those obtained for some forest ecosystems in the boreal zone (e.g. Kurganova et al., 2003; Wang et al., 2003) but were smaller than others (Russell and Voroney, 1998; Rayment and Jarvis, 2000; Domisch et al., 2006). Overestimation of soil surface efflux for the site covered mainly with a feather moss, Pleurozium schreberi, can be estimated to be some $10 \%$ for including moss dark respiration in conditions with an average efflux of $0.42 \mathrm{~g} \mathrm{CO}_{2} \mathrm{~m}^{-2} \mathrm{~h}^{-1}$, average water content in moss of $250 \%$, average air temperature at the time of measurements $15^{\circ} \mathrm{C}$ in 1999 , and assuming a similar optimum of moss water content for dark respiration as has been found for photosynthesis (see Silvola, 1985, 1992).
The range of soil $\mathrm{CO}_{2}$ efflux, 0.044-0.134 $\mathrm{g} \mathrm{CO}_{2} \mathrm{~m}^{-2} \mathrm{~h}^{-1}$ measured in winter in this study in a pine forest was smaller than that measured in a Finnish spruce stand (Domisch et al., 2006) but similar to the range of efflux in other boreal forests (Winston et al., 1997; Kurganova et al., 2003; Pumpanen et al., 2003a). Our estimates of soil $\mathrm{CO}_{2}$ efflux for the 6-month winter period were $240 \mathrm{~g} \mathrm{CO}_{2} \mathrm{~m}^{-2}$ for the winter of 1998 1999 and $510 \mathrm{~g} \mathrm{CO}_{2} \mathrm{~m}^{-2}$ for the following winter. The contribution of the snow-covered period to the annual estimate of soil $\mathrm{CO}_{2}$ emissions corresponded to the previously reported estimates, 5 to $22 \%$, for boreal forests with an equally long snow-covered period (Kurganova et al., 2003; Wang et al., 2003; Domisch et al., 2006). However, there is some uncertainty in winter $\mathrm{CO}_{2}$ efflux from soil in this study, because of the low frequency of measurements in winter. Auxiliary measurements in Novembers 1997-1999 (results not shown) made on thin snow cover of the time either on summertime collars or next to them depending on snow depth, with the same methodology than summertime efflux measurements, indicated that using observations made only during winter months with a well-insulating, i.e. thick snow cover could have lead to an overestimation of winter fluxes by some $10 \%$ and of annual sum by some 1-3\% depending on the winter in question. Thus more measurements with large chambers, especially early in the winter, would have been needed to acquire more accurate estimates of winter efflux.

The greater efflux in winter 1999-2000 compared to winter 1998-1999 could be explained by higher soil temperatures in January-April 2000, when temperatures remained around $0{ }^{\circ} \mathrm{C}$, as winter flux has been suggested to be sensitive to interannual variation in temperature (Winston et al.,1997). Differences in substrate availability and in snowpack structure could also have been contributing factors. The more layered snowpack early in 2000 could have caused $\mathrm{CO}_{2}$ to accumulate in soil more than it had under the better-aerated snowpack in 1999, which could have still been reflected in measured efflux after a snow removal because of slow diffusion of gases through a frozen surface of soil. Melt-freeze crusts in snow appeared to restrict transportation of $\mathrm{CO}_{2}$ for at least a month or two in late winter, contrary to earlier observations (Winston et al., 1997); but the extent of the restriction appeared to be dependent on the weather pattern in this climate.

\subsection{Seasonality of temperature response}

At a given temperature, soil $\mathrm{CO}_{2}$ efflux was observed to be higher later in the snow-free period than in spring and early summer, which is similar to findings in a Douglas-fir forest (Drewitt et al., 2002) and is supported by the monthspecific models and results for model evaluation in this study. Monthly averages and models agreed with earlier findings of greater efflux in autumn compared to spring at comparable temperatures in a temperate forest (Crill, 1991). Our monthly models resulted in a pattern of predicted soil $\mathrm{CO}_{2}$ 
efflux identical to that found in a Siberian pine forest study (Shibistova et al., 2002), with the month of May having the lowest $\mathrm{CO}_{2}$ efflux at $10^{\circ} \mathrm{C}$ and August having the highest. Variation in soil moisture did not explain the seasonality of the temperature response.

In our study, peak $\mathrm{CO}_{2}$ efflux occurred in July-August, and the highest soil $\mathrm{CO}_{2}$ efflux at a given temperature was found in August. Our results can be partly attributed to temporal variation in root-associated respiration. Although root growth was not monitored at our site, maximum root production usually lags by several weeks behind the aboveground growth of trees (e.g. Steinaker et al., 2010). At our site diameter growth typically started by the third week of June (Kellomäki, S. unpublished data). The annual increment in diameter of pines was small, about $1 \mathrm{~mm} \mathrm{a}^{-1}$ at a height of $1.3 \mathrm{~m}$, which made day-to-day monitoring of growth difficult. In our region, however, the fine root biomass and root growth in Scots pine forests have been observed to peak late in the summer or early autumn, in July, August or September, differing in different stands and from year to year (Makkonen and Helmisaari, 2001; Helmisaari et al., 2009).

Correspondingly, the peak root and mycorrhizal respiration in a Swedish tree-girdling experiment was observed in August, following a pattern similar to ours for maximum solar irradiance at the end of June and a period of high air- and soil temperatures in July (Högberg et al., 2001; Bhupinderpal-Singh et al., 2003). Results from this boreal pine-girdling experiment suggest a correlation between soil $\mathrm{CO}_{2}$ efflux and biomass of the external mycelium of ectomycorrhizal fungi, which can contribute $30-40 \%$ of the soil microbial biomass in our type of Scots pine stands (Högberg and Högberg, 2002). In addition to the fact that flux of photosynthates supports a considerable portion of soil microbial biomass consisting of ectomycorrhizal fungi, dissolved organic carbon from mycorrhizal fungi is also a potentially important source of carbon for other soil microbes (Högberg and Högberg, 2002).

Soil $\mathrm{CO}_{2}$ efflux during the peak season in mid-JulyAugust was underestimated by the soil temperature and degree days model of this study. Similar underestimation of $\mathrm{CO}_{2}$ efflux with a temperature response model covering the entire snow-free period was also observed by Kolari et al. (2009) for July-August in another Finnish Scots pine forest. The seasonal pattern of root growth and rapid growth of external mycelium of ectomycorrhizal fungi in coniferous boreal forests later in the season, from July to September or October, compared to the earlier part of the snow-free period (Wallander et al., 1997, 2001), could explain underestimation of $\mathrm{CO}_{2}$ efflux in mid-July-August by our models. Correspondingly, appearance of fruit bodies of ectomycorrhizal fungi inside individual collars occurred in our study from August to October which was associated with higher soil $\mathrm{CO}_{2}$ efflux from these measurement points.

The influence of fast flux of photosynthates on soil $\mathrm{CO}_{2}$ efflux, through the roots and root-associated respiration, has been suggested to be proportionally largest in the middle of the growing period; consequently, soil temperature may not exert major control on root respiration at that time, but recent aboveground weather conditions affecting photosynthesis may have an effect (Russell and Voroney, 1998; Ekblad et al., 2005). In the girdling experiment, sensitivity of root respiration to soil temperature was correspondingly found to be lower than that of heterotrophic respiration in midJuly and early August (Bhupinderpal-Singh et al., 2003). A greater proportion of soil $\mathrm{CO}_{2}$ originating from roots and root-associated respiration and greatly influenced by flux of photosynthates could help to explain the relative temperature insensitivity of soil $\mathrm{CO}_{2}$ efflux in our study in July compared to other parts of the snow-free period, especially as the highest monthly mean photosynthesis at our site has been measured for July (Zha et al., 2007). Others have also found a weak or no correlation between $\mathrm{CO}_{2}$ efflux from forest soil and soil temperature during the peak period of soil $\mathrm{CO}_{2}$ efflux and temperature in summer (Russell and Voroney, 1998; Kelliher et al.,1999; Curiel Yuste et al., 2004) or between efflux and soil temperature and moisture (Schlentner and VanCleve, 1985). In our study, variation in soil moisture did not clearly explain the variation in $\mathrm{CO}_{2}$ efflux in July, contrary to the results of a study in a Siberian pine forest (Kelliher et al., 1999).

The differences in the level of soil $\mathrm{CO}_{2}$ efflux at low temperatures between spring and autumn are most likely due to differences in temperatures within the soil column during warming and cooling (see Reichstein et al., 2005) and to differences in size of the volume of soil that is active, i.e. not waterlogged or frozen (Rayment and Jarvis, 2000). A similar hysteresis-type of pattern in the temperature response of the soil $\mathrm{CO}_{2}$ efflux has been observed in other forest studies with single-depth measurements of soil temperature during a snow-free period (e.g. Morén and Lindroth, 2000; Drewitt et al., 2002). A hysteresis of temperature response was also found in laboratory incubations of forest soils during warming and cooling treatments (Reichstein et al., 2005). Although most of the soil $\mathrm{CO}_{2}$ emissions have been estimated to originate from the organic humus layer in Finnish boreal forests throughout the year (Pumpanen et al., 2003b), the depth from which soil temperature is measured can cause seasonal differences in the perceived level of soil $\mathrm{CO}_{2}$ efflux at a given temperature (e.g. Drewitt et al., 2002). In addition to a possible discrepancy between the soil layer from which most of the $\mathrm{CO}_{2}$ originates and the soil layer in which temperature is measured, momentary temperatures in the surface soil may not reflect the conditions in which soil $\mathrm{CO}_{2}$ emissions have been produced and transported during a period preceding the measurements. The greatest overestimations with temperature models in this study were thus often associated with cool conditions in May and October with afternoon surface temperatures that were noticeably higher than the morning temperatures. 
In this study, a lack of appropriate temperature data prevented a thorough comparison and evaluation of models based on temperatures at different soil depths. The most comprehensive series of temperatures of the deeper soil layers was obtainable for the depth of $7 \mathrm{~cm}$ in the mineral soil in 1998-2000, with some gaps in 2000. A similar data series was not available for the evaluation measurements made in Mekrijärvi. The fact that the temperature had been measured in the organic layer, i.e. close to surface, contributed for the most part to the observed greater level of $\mathrm{CO}_{2}$ efflux at a given temperature in October compared to May. Auxiliary analyses with mineral soil temperatures at $7 \mathrm{~cm}$ produced an opposite pattern. Similar reverse hystereses of the temperature response were observed for the surface and central temperatures of forest soil columns during warming and cooling treatments in laboratory (Reichstein et al., 2005). Yet in our study, the temperature of the organic layer was a better predictor of soil $\mathrm{CO}_{2}$ efflux in May than the temperature at $7 \mathrm{~cm}$ depth in mineral soil was. In October, variation in these two temperatures explained approximately an equal proportion of the variation in soil $\mathrm{CO}_{2}$ efflux. In modelling temperature response with multiple soil temperatures, temperature of the organic layer was the only predictor selected in a step-wise procedure of a regression analysis for May. For October, an inclusion of temperature at $7 \mathrm{~cm}$ in mineral soil as an auxiliary predictor did not notably improve the model fit although the inclusion was statistically supported ( $p=0.03$ for an increase of 0.02 in $R^{2}$ ). Inclusion did not change the difference in the level of $\mathrm{CO}_{2}$ efflux at a given temperature of the organic layer between May and October (as in Fig. 5b).

The most appropriate depth to measure soil temperature is therefore not necessarily constant, as the soil $\mathrm{CO}_{2}$ efflux is influenced by the temperature of the soil column that should be taken into account as a whole (e.g. Morén and Lindroth, 2000). On the other hand, a contribution of the organic layer to soil $\mathrm{CO}_{2}$ efflux and its seasonal and annual variation have been found to be significant in many forest studies. Contribution has been estimated to be over $40 \%$ of the total annual soil $\mathrm{CO}_{2}$ efflux (Davidson et al., 2006b) and two thirds of the mineralized carbon of soil column samples (Kähkönen et al., 2002; Reichstein et al., 2005). However, combining temperatures at different depths, or a multi-layer approach such as applied by Pumpanen et al. (2003b), Reichstein et al. (2005) and Davidson et al. (2006b), could be ideal, especially for a season-specific modelling. In continuous, multiyear modelling in a temperate forest, the partitioning of $\mathrm{CO}_{2}$ production by horizon did not, however, improve the overall prediction of soil $\mathrm{CO}_{2}$ efflux based on temperature functions (Davidson et al., 2006b).

It was, however, encouraging to find that according to our auxiliary analysis, the quadratic surface soil temperature and degree days model explained as much of the variation in soil $\mathrm{CO}_{2}$ efflux in 1998-1999 as did a model with a combination of the temperatures of the organic layer and that at $7 \mathrm{~cm}$ in mineral soil as predictors. On the other hand, models that included temperature measured in mineral soil could not be comprehensively evaluated with independent soil $\mathrm{CO}_{2}$ efflux data measured in 2000 because of scarcity of the soil temperature data. Yet, our auxiliary analyses indicated that soil $\mathrm{CO}_{2}$ efflux was underestimated during the peak efflux in July-August also when the temperatures in the organic and topmost mineral soil layer were both included as predictors. The model with the temperatures measured at the two depths overestimated the soil $\mathrm{CO}_{2}$ emissions in spring and early summer i.e. in May and June but its performance in autumn could not be tested against independent soil $\mathrm{CO}_{2}$ efflux data because of the lack of appropriate soil temperature data.

Although difference in temperature response between early and late in the snow-free period mostly originated from the use of temperature measured at a single, constant depth in soil, seasonally variable factors such as substrate availability and composition of the microbial population could have influenced soil $\mathrm{CO}_{2}$ efflux as well. Microbial populations have been observed to decline in spring after snowmelt but increase during autumn (Lipson et al., 1999, 2000). Correspondingly, mineralization of soil carbon has been found to be greater in samples collected in Finnish forests in October than in samples collected in May (Kähkönen et al., 2002). The supply of photosynthates to the roots has also been found to be smaller in forests in spring than in autumn (Keel et al., 2006), which in our study could have resulted in lower root respiration and, through a priming effect, also in lower microbial respiration in spring. Growth of ectomycorrhizal fungi has correspondingly been observed to be more rapid from July until September or October than in spring or early summer (Wallander et al., 1997, 2001). Also in our study, appearance of fruit bodies of ectomycorrhizal fungi inside individual collars occurred from August to October which was associated with higher soil $\mathrm{CO}_{2}$ efflux from these measurement points.

In addition, fresh carbon inputs in the form of needle litter during the latter part of the snow-free period may have had a positive effect on level of soil $\mathrm{CO}_{2}$ efflux. Needle litterfall peaked at our site in late summer and early autumn, similarly to a study on a the temporal pattern of needle litterfall in Finnish pine forests (Ukonmaanaho, 2007). Together the needle litterfall in August and September formed half of the annual needle litterfall at our site (Niinistö, S. M. unpublished data). Although the amount of litter from dwarf shrubs of the understorey can be small compared to tree litter in this kind of pine forests (Hilli et al., 2008), the senescence of dwarf shrubs, especially $V$. myrtillus at our site, could have provided a fresh input of carbon to $\mathrm{CO}_{2}$ producing soil microbes in the autumn.

\subsection{Response of $\mathrm{CO}_{2}$ efflux to moisture}

The overall response of soil $\mathrm{CO}_{2}$ efflux to moisture at our site in the dry year 1999 resembled the response measured in a temperate forest where dry conditions decreased soil 
$\mathrm{CO}_{2}$ efflux in August and September, whereas with increasing moisture there was a decreasing trend early and late in the year (Davidson et al., 1998). Negative effects of dry conditions on soil $\mathrm{CO}_{2}$ efflux previously found in temperate and boreal forests (Savage and Davidson, 2001; Subke et al., 2003; Kolari et al., 2009) were evident in our forest also when shorter periods of time were compared. Efflux was $30 \%$ lower in September of the dry year 1999 (precipitation in the snow-free period $50 \%$ of that in 1998) compared to the previous September, with a similar mean soil temperature and temperature range. A corresponding decrease in microbial respiration was observed in Finnish forest soils during a dry August (Vanhala, 2002).

There was a decline in measured soil $\mathrm{CO}_{2}$ efflux with an increase in soil moisture at the high end of the range. It is unlikely that even at the high levels of soil moisture at our site, the requirements of sufficient aeration would not have been met in the coarse and well-drained sandy till in question, i.e. the production processes of $\mathrm{CO}_{2}$ were probably not hindered by excess moisture. According to calculations based on $45 \%$ porosity with stoniness accounted for, the soil air space in our experiment ranged from 0.21 to $0.29 \mathrm{~m}^{3} \mathrm{~m}^{-3}$ (1998) and to $0.40 \mathrm{~m}^{3} \mathrm{~m}^{-3}$ (1999). Moreover, the approximated optimum water content in the $\mathrm{B}$ horizon for soil $\mathrm{CO}_{2}$ efflux, $0.25-0.30 \mathrm{~m}^{3} \mathrm{~m}^{-3}$ for our soil (based on the model by Skopp et al. (1990) and adapted for a Finnish till by Pumpanen et al., 2003b), was not exceeded even in the wet year of 1998. Similarly, no decrease in microbial $\mathrm{CO}_{2}$ production, and consequently $\mathrm{CO}_{2}$ evolution, was detected for a type of mineral soil similar to ours nor for a similar type of organic layer, i.e. boreal mor in conditions close to saturation, at water contents exceeding ours (Ilstedt et al., 2000; Schjønning et al., 2003).

The negative relationship between soil $\mathrm{CO}_{2}$ efflux and soil moisture at high soil moisture observed in our study could thus have been an artifact, reflecting not the influence of soil moisture per se but rather some other covarying factor - such as temperature (Carlyle and Than, 1988; Davidson et al., 1998). On the other hand, the negative relation between $\mathrm{CO}_{2}$ efflux on the soil surface and soil moisture could be partly due to high moisture slowing or preventing the transportation of $\mathrm{CO}_{2}$. In our case, there was a strong correlation between time and soil moisture during the first half of the snow-free period, which suggests that in our multivariable regression models soil moisture, with its negative regression coefficient, could have been a surrogate for time, i.e. progress of the growing season and associated processes when soil moisture decreased steadily after snow melt in early May. The same temporal pattern of soil moisture and the similar negative correlation between soil moisture and coniferous root growth have been observed during a snow-free period in Canada (Steinaker et al., 2010). In our month-specific analyses there was also no evidence of a decline associated with high soil moisture. As noted before (e.g. Kane et al., 2003), our data, i.e. soil $\mathrm{CO}_{2}$ efflux observations together with simultaneous measurements of natural variation of soil moisture, do not, however, enable us to properly distinguish between the effects of soil moisture and time, i.e. seasonality or temperature.

Inclusion of the moisture of moss, litter or the organic layer did not improve models that already included moisture of mineral soil as a variable. The intensity of soil $\mathrm{CO}_{2}$ efflux measurements or gravimetric sampling may not have been great enough to capture short-term efflux fluctuations from these layers nor to capture the effect of smaller rain events, which has been found to be transient, but possibly significant (Kelliher et al., 1999; Savage and Davidson, 2003).

\subsection{Multivariable approach}

Temperature probably functioned as such a good predictor because many environmental factors and ecosystem processes, such as solar irradiation, carbon uptake and plant growth, varied in concert with its variation in this boreal ecosystem over a typical "arch" of the snow-free period (e.g. Euskirchen et al., 2003). Temperature may also have acted as a proxy for other environmental variables, conditions and processes, thus calling temperature models "temperature-associated response models" may be justified. Although temperature of the organic humus layer was found to be a good predictor of soil $\mathrm{CO}_{2}$ efflux in this study, use of temperature from several depths could further improve the ability of models to predict $\mathrm{CO}_{2}$ efflux, especially during warming and cooling periods (Reichstein et al., 2005). Taking into account deeper soil layers would especially be advisable when soil $\mathrm{CO}_{2}$ emissions are modelled in similar boreal forests during late autumn or winter and during severe droughts (Pumpanen et al., 2003b).

Different processes producing soil $\mathrm{CO}_{2}$ efflux respond to changes in environmental conditions with different time lags; thus averages of environmental factors, such as the $24 \mathrm{~h}$ average of soil temperature in this study, make reasonable predictors of soil $\mathrm{CO}_{2}$ efflux. Transport of substrates to $\mathrm{CO}_{2-}$ producing processes and transport of produced $\mathrm{CO}_{2}$ are also influenced by prevailing conditions, which further complicates assessment of response times. For instance, flux between photosynthesis of tree canopy and soil $\mathrm{CO}_{2}$ efflux has been found to be relatively rapid, 1-6 days through root and rhizosphere respiration, i.e. autotrophic respiration together with mycorrhizal and free microbial respiration (Ekblad and Högberg, 2001; Ekblad et al., 2005), but seasonally variable in magnitude (Keel et al., 2006). The link between canopy photosynthesis and soil $\mathrm{CO}_{2}$ efflux will not, however, render the concept of temperature response of soil $\mathrm{CO}_{2}$ efflux useless in boreal forests, partly due to the proxy-like quality of temperature and partly because of the controlling effect of temperature on heterotrophic respiration, the proportion of which may be greater in boreal coniferous forests than in temperate forests (Subke et al., 2006). 
There is a need for more process-based models that take into account the question of substrate supply and distinguish between the direct effects of temperature and moisture and their effects on substrate diffusion and availability (Davidson et al., 2006a). The phenology of the ecosystem regulates the substrate supply to the soil $\mathrm{CO}_{2}$ efflux and to ecosystem respiration in general. It can explain some of the variation not accounted for by temperature-associated variation (Goulden et al., 1997). Accordingly, the basal rate of soil respiration has been found to vary seasonally with photosynthesis in temperate forest stands (Sampson et al., 2007). Inclusion of additional, seasonally changing variables such as needle litter input in our models proved to be difficult partly because of different intensity of the measurements. Also, time lags after which these variables could be considered to influence soil $\mathrm{CO}_{2}$ efflux, were difficult to define. However, an addition of an index of seasonality, such as the degree days, improved the accuracy of models in this study, as has been reported previously for respiration and soil $\mathrm{CO}_{2}$ efflux in boreal forests (Goulden et al., 1997; Lavigne et al., 1997; Richardson et al., 2006). This addition was supported by a model-evaluation exercise, although the consistent underestimation of flux during the peak season from mid-July to lateAugust was not corrected for. Differences between annual estimates produced with different models were yet small. Our results from the peak flux period in July and August, however, lent support to previous conclusions concerning the importance of inclusion of canopy processes (e.g. Irvine et al., 2005; Sampson et al., 2007), for upper-storey trees as well as understorey dwarf shrubs. Model predictions could also be improved by inclusion of the dynamics of root and mycorrhizal fungi production, which can be significant covarying processes of soil $\mathrm{CO}_{2}$ efflux in boreal forests (Högberg and Högberg, 2002). Extremely high, but sporadic, values of efflux that were possibly related to fungal activity, appeared to be difficult to predict. Our observations on the timing of these maximum values possibly related to fungal activity stress the need to link predictions of fungal respiration with the phase of the growing season and possibly with precipitation patterns.

Models of season-specific temperature and moisture response could be a step forward and provide less biased estimates by accounting for driving variables that are not explicitly included in the model (e.g. DeForest et al., 2006). In conditions of pronounced seasonal variation of boreal forests, shorter-term models that take into account the phase of the season would help distinguish between the effects of temperature, moisture and above- and belowground phenological development. In addition, watering experiments could give valuable insight into the role of soil moisture also in boreal forest ecosystems.

\section{Appendix A}

\section{Soil-specific calibration on Campbell's CS615 water content reflectometers}

Soil-specific calibration was carried out separately for the topmost $30 \mathrm{~cm}$ of mineral soil (density $0.98 \mathrm{~g} \mathrm{~cm}^{-3}$ ) and for the undisturbed sheet of the organic layer, which also contained some of the topmost mineral soil (density of $0.31 \mathrm{~g} \mathrm{~cm}^{-3}$ ). Samples in large buckets (diameter $28 \mathrm{~cm}$, $n=3$ ) were saturated with water; eight measurements were made for each water content, and samples were weighed during drying at room temperature. Finally, to determine the dry mass, mineral soil samples were dried at $105^{\circ} \mathrm{C}$ and the organic/surface soil layer at $70^{\circ} \mathrm{C}$. During calibration, water content was $0.14-0.43 \mathrm{~m}^{3} \mathrm{~m}^{-3}$ for the surface layer and $0.06-0.51 \mathrm{~m}^{3} \mathrm{~m}^{-3}$ for the mineral soil; the sensor output was $0.88-1.30 \mathrm{~ms}$ for the surface layer and $0.80-1.25 \mathrm{~ms}$ for mineral soil, which corresponded to the range in the field during May-October. Linear regressions were run with an output period $(\tau)$ in milliseconds at $20^{\circ} \mathrm{C}$ as the independent variable and the volumetric soil water content $(\theta)$ in $\mathrm{m}^{3} \mathrm{~m}^{-3}$ as the dependent variable for mineral and surface soil separately. Regression models were the following: $\theta=-0.679+0.923 \cdot \tau$, with $r^{2}=0.98$ (mineral soil), and $\theta=-0.374+0.616 \cdot \tau$, with $r^{2}=0.96$ (organic layer/surface soil).

The equation for mineral soil was similar to a previous calibration made for sandy soils with the same sensor (Kim and Benson, 2002). Compared to the soil-specific calibration, the manufacturer's standard calibration underestimated some 3 to $20-30 \%$ or $0-0.07 \mathrm{~m}^{3} \mathrm{~m}^{-3}$ for mineral soil within the output range in the field in 1999. This was considerably less than, for instance, in a case of tropical clay soils (Veldkamp and O'Brien, 2000). The manufacturer's standard calibration equation applied here was for conditions in which electrical conductivity was equal to or smaller than $1 \mathrm{dS} \mathrm{m}^{-1}$ (Campbell Scientific Inc., 1999).

Acknowledgements. We thank the staff at Mekrijärvi Research Station, especially Matti Lemettinen and Alpo Hassinen, for technical support, Ismo Rouvinen and Sanna Leinonen for help with meteorological data, and Tuula Larmola, Sari Juutinen and Jussi Lintunen for advice in the field and in the office. We also thank Hannu Mannerkoski for discussions on soil properties and water content, Alf Ekblad for discussions on dynamics of mycorrhizal fungi and Joann von Weissenberg for language revision. This work forms part of the Finnish Centre of Excellence Programme (Project no. 64308) funded by the Academy of Finland, the National Technology Agency (Tekes), and the University of Joensuu/University of Eastern Finland. Funding granted to S. M. Niinistö by Kone, Nessling, Niemi and the Metsämiesten Säätiö Foundations, the Finnish Cultural Foundation and the Science Foundation for Women is gratefully acknowledged.

Edited by: P. Stoy 


\section{References}

Anderson, J. M.: Carbon dioxide evolution from two temperate, deciduous woodland soils, J. Appl. Ecol., 10, 361-378, 1973.

Bhupinderpal-Singh, Nordgren, A., Ottosson Löfvenius, M., Högberg, M. N., Mellander, P.-E., and Högberg. P.: Tree root and soil heterotrophic respiration as revealed by girdling of boreal Scots pine forest: extending observations beyond the first year, Plant. Cell. Environ., 26, 1287-1296, 2003.

Bowden, R. D., Nadelhoffer, K. J., Boone, R. D., Melillo, J. M., and Garrison, J. B.: Contributions of aboveground litter, belowground litter, and root respiration to total soil respiration in a temperate mixed hardwood forest, Can. J. Forest Res., 23, 14021407, 1993.

Campbell Scientific Inc.: CS615 Water content reflectometer: User guide, Campbell Scientific Inc., 17 pp., 1999.

Carlyle, J. C. and Than, U. B.: Abiotic controls of soil respiration beneath an eighteen-year-old Pinus radiata stand in south-eastern Australia, J. Ecol., 76, 654-662, 1988.

Crill, P. M.: Seasonal patterns of methane uptake and carbon dioxide release by a temperate woodland soil, Global Biogeochem. Cy., 5, 319-334, 1991.

Curiel Yuste, J., Janssens, I. A., Carrara, A., and Ceulemans, R.: Annual $Q_{10}$ of soil respiration reflects plant phenological patterns as well as temperature sensitivity, Global Change Biol., 10, 161-169, 2004.

Davidson, E. A., Belk, E., and Boone, R. D.: Soil water content and temperature as independent or confounded factors controlling soil respiration in a temperate mixed hardwood forest, Global Change Biol., 4, 217-227, 1998.

Davidson, E. A., Janssens, I. A., and Luo, Y.: On the variability of respiration in terrestrial ecosystems: moving beyond $Q_{10}$, Global Change Biol., 12, 154-164, 2006a.

Davidson, E. A., Savage, K. E., Trumbore, S. E., and Borken, W.: Vertical partitioning of $\mathrm{CO}_{2}$ production within a temperate forest soil, Global Change Biol., 12, 944-956, 2006 b.

DeForest, J. L., Noormets, A., McNulty, S. G., Sun, G., Tenney, G., and Chen, J.: Phenophases alter the soil respiration-temperature relationship in an oak-dominated forest, Int. J. Biometeorol., 51, 135-144, 2006.

Domisch, T., Finér, L., Ohashi, M., Risch, A. C., Sundström, L., Niemelä, P., and Jurgensen, M. F.: Contribution of red wood ant mounds to forest floor $\mathrm{CO}_{2}$ efflux in boreal coniferous forests, Soil Biol. Biochem., 38, 2425-2433, 2006.

Drebs, A., Nordlund, A., Karlsson, P., Helminen, J., and Rissanen, P.: Climatological statistics of Finland 1971-2000, Climatic Statistics of Finland, 2002:1, 1-99, 2002.

Drewitt, G. B., Black, T. A., Nesic, Z., Humphreys, E. R., Jork, E. M., Swanson, R., Ethier, G. J., Griffis, T., and Morgenstern, K.: Measuring forest floor $\mathrm{CO}_{2}$ fluxes in a Douglas-fir forest, Agr. Forest Meteor., 110, 299-317, 2002.

Ekblad, A. and Högberg, P.: Natural abundance of ${ }^{13} \mathrm{C}$ in $\mathrm{CO}_{2}$ respired from forest soils reveals speed of link between tree photosynthesis and root respiration, Oecologia ,127, 305-308, 2001.

Ekblad, A., Boström, B., Holm, A., and Comstedt, D.: Forest soil respiration rate and $\delta^{13} \mathrm{C}$ is regulated by recent above ground weather conditions, Oecologia, 143, 136-142, 2005.

Euskirchen, E. S., Chen, J., Gustafson, E. J., and Ma, S.: Soil respiration at dominant patch types within a managed northern Wisconsin landscape, Ecosystems, 6, 595-607, 2003.
Goulden, M. L., Daube, B. C, Fan, S.-M., Sutton, D. J., Bazzaz, A., Munger, J. W., and Wofsy, S. C.: Physiological responses of a black spruce forest to weather, J. Geophys. Res., 102, 2898728996, 1997.

Helmisaari, H.-S., Ostonen, I., Lõhmus, K., Derome, J., Lindroos, A.-J., Merilä, P., and Nöjd, P.: Ectomycorrhizal root tips in relation to site and stand characteristics in Norway spruce and Scots pine stands in boreal forests, Tree Physiol., 29, 445-456, 2009.

Hilli, S., Stark, S., and Derome, J.: Water-extractable organic compounds in different components of the litter layer of boreal coniferous forest soils along a climatic gradient, Boreal Environ. Res., 13 (Suppl.B), 92-106, 2008.

Högberg, M. N. and Högberg, P.: Extramatrical ectomycorrhizal mycelium contributes one-third of microbial biomass and produces, together with associated roots, half the dissolved organic carbon in a forest soil, New Phytol., 154, 791-795, 2002.

Högberg, P., Nordgren, A., Buchmann, N., Taylor, A. F. S., Ekblad, A., Högberg, M. N., Nyberg, G., Ottosson-Löfvenius, M., and Read, D. J.: Large-scale forest girdling shows that current photosynthesis drives soil respiration, Nature, 411, 789-792, 2001.

Howard, D. M. and Howard, P. J. A.: Relationships between $\mathrm{CO}_{2}$ evolution, moisture content and temperature for a range of soil types, Soil Biol. Biochem., 25, 1537-1546, 1993.

Ilstedt, U., Nordgren, A., and Malmer, A.: Optimum soil water for soil respiration before and after amendment with glucose in humid tropical acrisols and a boreal mor layer, Soil Biol. Biochem., 32, 1591-1599, 2000.

Irvine, J., Law, B. E., Kurpius, M. R.: Coupling of canopy exchange with root and rhizosphere respiration in a semi-arid forest, Biogeochemistry, 73, 271-282, 2005.

Janssens, I. A. and Pilegaard, K.: Large seasonal changes in $Q_{10}$ of soil respiration in a beech forest, Global Change Biol., 9, 911918, 2003.

Janssens, I. A., Lankreijer, H., Matteucci, G., Kowalski, A. S., Buchmann, N., Epron, D., Pilegaard, K., Kutsch, W., Longdoz, B., Grünwald, T., Montagnani, L., Dore, S., Rebmann, C., Moors, E. J., Grelle, A., Rannik, Ü., Morgenstern, K., Oltchev, S., Clement, R., Guðmundsson, J., Minerbi, S., Berbigier, P., Ibrom, A., Moncrieff, J., Aubinet, M., Bernhofer, C., Jensen, N. O., Vesala, T., Granier, A., Schulze, E.-D., Lindroth, A., Dolman, A. J., Jarvis, P. G., Ceulemans, R., and Valentini, R. V.: Productivity overshadows temperature in determining soil and ecosystem respiration across European forest, Global Change Biol., 7, 269-278, 2001.

Kane, E. S., Pregitzer, K. S., and Burton, A. J.: Soil respiration along environmental gradients in Olympic National Park, Ecosystems, 6, 326-335, 2003.

Kähkönen, M. A., Wittmann, C., Ilvesniemi, H., Westman, C. J., and Salkinoja-Salonen, M. S.: Mineralization of detritus and oxidation of methane in acid boreal coniferous forest soils: seasonal and vertical distribution and effects of clear-cut, Soil Biol. Biochem., 34, 1191-1200, 2002.

Keel, S. G., Siegwolf, R. T. W., and Körner, C.: Canopy $\mathrm{CO}_{2}$ enrichment permits tracing the fate of recently assimilated carbon in a mature deciduous forest, New Phytol., 172, 319-329, 2006.

Kelliher, F. M., Lloyd, J., Arneth, A., Lühker, B., Byers, J. N., McSeveny, T. M., Milukova, I., Grigoriev, S., Panfyorov, M., Sogatchev, A., Varlagin, A., Ziegler, W., Bauer, G., Wong, S.-C., and Schulze, E.-D.: Carbon dioxide efflux density from the for- 
est floor of a central Siberian pine forest, Agric. Forest Meteorol., 94, 217-232, 1999.

Kellomäki, S. and Wang, K.-Y.: Short-term environmental controls on heat and water fluxes above a boreal coniferous forest: model computations compared with measurements by eddy correlation, Ecol. Model., 124, 145-173, 1999.

Kim, K. C. and Benson, C. H.: Water content reflectometer calibrations for final cover soils, Geo Engineering Report, No. 02-12. Geo Engineering Program, University of Wisconsin-Madison, Madison, Wisconsin, USA, 110 pp., 2002.

Klute, A.: Water retention: Laboratory methods, in: Methods of Soil Analysis, Part 1. Physical and Mineralogical Methods, 2 Edn., edited by: Klute, A., 635-662, Agronomy Monograph No. 9, American Society of Agronomy and Soil Science Society of America, Madison, WI, USA, 1986.

Kolari, P., Kulmala, L., Pumpanen, J., Launiainen, S., Ilvesniemi, H., Hari, P., and Nikinmaa, E.: $\mathrm{CO}_{2}$ exchange and component $\mathrm{CO}_{2}$ fluxes of a boreal Scots pine forest, Boreal Environ. Res., 14, 761-783, 2009.

Kurganova, I., Lopes de Gerenyu, V., Rozanova, L., Sapronov, D., Myakshina, T., and Kudeyarov, V.: Annual and seasonal $\mathrm{CO}_{2}$ fluxes from Russian southern taiga soils, Tellus, 55B, 338-344, 2003.

Larmola, T., Alm, J., Juutinen, S., Huttunen, J. T., Martikainen, P. J., and Silvola, J.: Contribution of vegetated littoral zone to winter fluxes of carbon dioxide and methane from boreal lakes, J. Geophys. Res., 109, D19102, doi:10.1029/2004JD004875, 2004.

Lavigne, M. B., Ryan, M. G., Anderson, D. E., Baldocchi, D. D., Crill, P. M., Fitzjarrald, D. R., Goulden, M. L., Gower, S. T., Massheder, J. M., McCaughey, J. H., Rayment, M., and Striegl, R. G.: Comparing nocturnal eddy covariance measurements to estimates of ecosystem respiration made by scaling chamber measurements at six coniferous boreal sites, J. Geophys. Res., 102, 28977-28985, 1997.

Linder, S. and Lohammer, T.: Amount and quality of information on $\mathrm{CO}_{2}$-exchange required for estimating annual carbon balance of coniferous trees, in: Understanding and predicting tree growth, edited by: Linder, S., Studia Forestalia Suecica, 160, 73-87, 1981.

Lipson, D. A., Schmidt, S. K., and Monson, R. K.: Links between microbial population dynamics and nitrogen availability in an alpine ecosystem, Ecology, 80, 1623-1631, 1999.

Lipson, D. A., Schmidt, S. K., and Monson, R. K.: Carbon availability and temperature control the post-snowmelt decline in alpine soil microbial biomass, Soil Biol. Biochem., 32, 441-448, 2000.

Lloyd, J. and Taylor, J. A.: On the temperature dependence of soil respiration, Funct. Ecol., 8, 315-323, 1994.

Makkonen, K. and Helmisaari, H.-S.: Fine root biomass and production in Scots pine stands in relation to stand age, Tree Physiol., 21, 193-198, 2001.

Morén, A.-S. and Lindroth, A.: $\mathrm{CO}_{2}$ exchange at the floor of a boreal forest, Agr. Forest Meteor., 101, 1-14, 2000.

Niinistö, S. M., Silvola, J., and Kellomäki, S.: Soil $\mathrm{CO}_{2}$ efflux in a boreal pine forest under atmospheric $\mathrm{CO}_{2}$ enrichment and air warming, Global Change Biol., 10, 1363-1376, 2004.

Pajari, B.: Soil respiration in a poor upland site of Scots pine stand subjected to elevated temperatures and atmospheric carbon concentration, Plant. Soil, 168-169, 563-570, 1995.
Pumpanen, J., Ilvesniemi, H., Perämäki, M., and Hari, P.: Seasonal patterns of soil $\mathrm{CO}_{2}$ efflux and soil air $\mathrm{CO}_{2}$ concentration in a Scots pine forest: comparison of two chamber techniques, Global Change Biol., 9, 371-382, 2003a.

Pumpanen, J., Ilvesniemi, H., and Hari,. P.: A process-based model for predicting soil carbon dioxide efflux and concentration, Soil Sci. Soc. Am. J., 67, 402-413, 2003 b.

Pumpanen, J., Kolari, P., Ilvesniemi, H., Minkkinen, K., Vesala, T., Niinistö, S., Lohila, A., Larmola, T., Morero, M., Pihlatie, M., Janssens, I., Curiel Yuste, J., Grünzweig, J. M., Reth, S., Subke, J.-A., Savage, K., Kutsch, W., Østreng, G., Ziegler, W., Anthoni, P., Lindroth, A., and Hari, P.: Comparison of different chamber techniques for measuring soil $\mathrm{CO}_{2}$ efflux, Agric. Forest Meteorol., 123, 159-176, 2004.

Raich, J. W. and Schlesinger, W. H.: The global carbon dioxide flux in soil respiration and its relationship to vegetation and climate, Tellus, 44B, 81-99, 1992.

Rayment, M. B. and Jarvis, P. G .: Temporal and spatial variation of soil $\mathrm{CO}_{2}$ efflux in a Canadian boreal forest, Soil Biol. Biochem., 32, 35-45, 2000.

Reichstein, M., Subke, J.-A., Angeli, A. C., and Tenhunen, J. D.: Does the temperature sensitivity of decomposition of soil organic matter depend upon water content, soil horizon, or incubation time? Global Change Biol., 11, 1754-1767, 2005.

Richardson, A. D., Braswell, B. H., Hollinger, D. Y., Burman, P., Davidson, E. A., Evans, R. S., Flanagan, L. B., Munger, J. W., Savage, K., Urbanski, S. P., and Wofsy, S. C.: Comparing simple respiration models for eddy flux and dynamic chamber data, Agric. Forest Meteorol., 141, 219-234, 2006.

Russell, C. A. and Voroney, R. P.: Carbon dioxide efflux from the floor of a boreal aspen forest, I., Relationship to environmental variables and estimates of C respired, Can. J. Soil Sci., 78, 301310, 1998.

Rustad, L. E., Huntington, T. G., and Boone, R. D.: Controls on soil respiration: Implications for climate change, Biogeochemistry, 48, 1-6, 2000 .

Sampson, D. A., Janssens, I. A., Curiel Yuste, J., and Ceulemans, R.: Basal rates of soil respiration are correlated with photosynthesis in a mixed temperate forest, Global Change Biol., 13, 2008-2017, 2007.

Savage, K. E. and Davidson, E. A.: Interannual variation of soil respiration in two New England forests, Global Biogeochem. Cy., 15, 337-350, 2001.

Savage, K. E. and Davidson, E. A.: A comparison of manual and automated systems for soil $\mathrm{CO}_{2}$ measurements: trade-off between spatial and temporal resolution, J. Exp. Bot., 54, 891-899, 2003.

Schjønning, P., Thomsen, I. K., Moldrup, P., and Christensen, B. T.: Linking soil microbial activity to water- and air-phase contents and diffusivities, Soil Sci. Soc. Am. J., 67, 156-165. 2003.

Schlentner, R. E. and Van Cleve, K.: Relationships between $\mathrm{CO}_{2}$ evolution from soil, substrate temperature, and substrate moisture in four mature forest types in interior Alaska, Can. J. Forest Res., 15, 97-106, 1985.

Schlesinger, W. H.: Carbon balance in terrestrial detritus, Annu. Rev. Ecol. Syst., 8, 51-81, 1977.

Shibistova, O., Lloyd, J., Zrazhevskaya, G., Arneth, A., Kolle, O., Knohl, A., Astrakhantceva, N., Shijneva, I., and Schmerler, J.: Annual ecosystem respiration budget for a Pinus sylvestris stand in central Siberia, Tellus, 54B, 568-589, 2002. 
Silvola, J.: $\mathrm{CO}_{2}$ dependence of photosynthesis in certain boreal forest and peat mosses and simulated photosynthesis at various actual and hypothetical $\mathrm{CO}_{2}$ concentrations, Lindbergia, 11, 8693, 1985.

Silvola, J.: Moisture dependence of $\mathrm{CO}_{2}$ exchange and its recovery after drying in certain boreal forest and peat mosses, Lindbergia, 17, 5-10, 1992.

Skopp. J., Jawson, M. D., and Doran, J. W.: Steady-state aerobic microbial activity as a function of soil water content, Soil Sci. Soc. Am. J., 54, 1619-1625, 1990.

Steinaker, D.-F., Wilson, S. D., and Peltzer, D. A.: Asynchronicity in root and shoot phenology in grasses and woody plants, Global Change Biol., 16, 2241-2251, 2010.

Subke, J.-A., Reichstein, M., and Tenhunen, J. D.: Explaining temporal variation in soil $\mathrm{CO}_{2}$ efflux in a mature spruce forest in Southern Germany, Soil Biol. Biochem., 35, 1467-1483, 2003.

Subke, J.-A., Inglima, I., and Cotrufo, M. F.: Trends and methodological impacts in soil $\mathrm{CO}_{2}$ efflux partitioning: A metaanalytical review, Global Change Biol., 12, 921-943, 2006.

Teskey, R. O., Whitehead, D., and Linder, S.: Photosynthesis and carbon gain by pines, Ecol. Bull., 43, 35-49, 1994.

Ukonmaanaho, L.: Litterfall production on 14 Level II plots during 1996-2003, Working Papers of the Finnish Forest Research Institute, 45, 63-68, 2007.

Vanhala, P.: Seasonal variation in the soil respiration rate in coniferous forest soils, Soil Biol. Biochem., 34, 1375-1379, 2002.
Veldkamp, E. and O'Brien, J. J.: Calibration of a frequency reflectometry sensor for humid tropical soils of volcanic origin, Soil Sci. Soc. Am. J., 64, 1549-1553, 2000.

Wallander, H., Massicotte, H. B., and Nylund, J.-E.: Seasonal variation in protein, ergosterol and chitin in five morphotypes of Pinus sylvestris L. ectomycorrhizae in a mature Swedish forest, Soil Biol. Biochem., 29, 45-53, 1997.

Wallander, H., Nilsson, L. O., Hagerberg, D., and Bååth, E.: Estimation of the biomass and seasonal growth of external mycelium of ecotomycorrhizal fungi in the field, New Phytol., 151, 753760, 2001.

Wang, C., Bond-Lamberty, B., and Gower, S. T.: Soil surface $\mathrm{CO}_{2}$ flux in a boreal black fire chronosequence, J. Geophys. Res., 108, 8224, doi:10.1029/2001JD000861, 2003.

Winston, G. C., Sundquist, E. T., Stephens, B. B., and Trumbore, S. E.: Winter $\mathrm{CO}_{2}$ fluxes in a boreal forest, J. Geophys. Res., 102, 28795-28804, 1997.

Witkamp, M.: Rates of carbon dioxide evolution from the forest floor, Ecology, 47, 492-494, 1966.

Zar, J. H.: Biostatistical Analysis, Prentice-Hall, Upper Saddle River, NJ, USA, 1999.

Zha, T., Niinistö, S., Xing, Z., Wang, K.-Y., Kellomäki, S., and Barr, A. G.: Total and component carbon fluxes of a Scots pine ecosystem from chamber measurements and eddy covariance, Ann. Bot. London, 99, 345-353, 2007. 